\title{
Holothuriophilus trapeziformis Nauck, 1880 (Decapoda: Pinnotheridae) from the Pacific coast of Mexico: Taxonomic revision based on integrative taxonomy
}

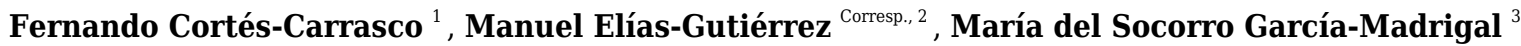 \\ ${ }^{1}$ Departamento de Sistemática y Ecología Acuática, El Colegio de la Frontera Sur unidad Chetumal, Chetumal, Quintana Roo, Mexico \\ 2 Departamento de Sistemática y Ecología Acuática, El Colegio de la Frontera Sur, Chetumal, Quintana Roo, Mexico \\ 3 Laboratorio de Sistemática de Invertebrados Marinos (LABSIM), Universidad del Mar, Puerto Ángel, Oaxaca, Mexico \\ Corresponding Author: Manuel Elías-Gutiérrez \\ Email address: melias@ecosur.mx
}

Background. Holothuriophilus trapeziformis Nauck, 1880 is a holothurian-dweller pinnotherid crab representing one of the two species of the genus distributed along the Pacific coast of Mexico and Chile, respectively. While the parasitic ecological interaction with its host is well established, the morphology of the male remains unknown, and DNA information for the species is not available. Furthermore, the only morphological trait separating both species of the genus is subjective and corresponds to the presence or absence of a gap between the fingers of the chelae. Our goal is to complete and clarify the taxonomic status of $H$. trapeziformis and describe the male morphology with the use of the integrative taxonomy, providing additional characters to differentiate this species.

Methods. We collected new biological material in the Pacific coast of Mexico including the topotypes. We also reviewed material from national collections to integrate morphology (based on a complete and detailed description and illustration of the species using light microscopy), ecological data (based on the identification of the host and the place where it was located within the host), and the mtCOI gene information (commonly known as DNA barcode) to differentiate Holothuriophilus trapeziformis from other related crabs.

Results. This species presents marked sexual dimorphism only in the primary sexual characters. For the first time we describe morphological variability of traditionally stable characters. In addition to the gap between the fingers of the chelae, Holothuriophilus trapeziformis differs from $\mathrm{H}$. pacificus (Poeppig, 1836) by their ornamentation, the shape of the male abdomen, and the gonopod. COl distance divergence was $>3 \%$ between both Holothuriophilus species forming a clear clade. DNA barcoding indicates only one taxon, with a maximum divergence of $2.2 \%$. All the specimens have the same Barcode Index Number (BIN; BOLD: ADE9974). All the hosts for $\mathrm{H}$. trapeziformis were identified as Holothuria (Halodeima) inornata Semper, 1868; the presence of the crab in the host's coelomic cavity was confirmed, and for the first time we found it within the intestine. The geographical distribution is the Pacific coast of Mexico. Based on the data presented here, the taxonomic status of Holothuriophilus trapeziformis is now complete. 
Holothuriophilus trapeziformis Nauck, 1880 (Decapoda: Pinnotheridae) from the Pacific 11

Fernando Cortés-Carrasco $^{1}$, Manuel Elías-Gutiérrez ${ }^{*}$, María del Socorro García-Madrigal²

${ }^{1}$ Departamento de Sistemática y Ecología Acuática, Zooplancton y Oceanografía. El Colegio de la Frontera Sur unidad Chetumal, Avenida Centenario km 5.5, Apdo. Postal 424, 77000, Chetumal, Quintana Roo, México.

${ }^{2}$ Laboratorio de Sistemática de Invertebrados Marinos, Universidad del Mar, Campus Puerto Ángel, Ciudad Universitaria, Apdo. Postal 47, 70902, Puerto Ángel, Oaxaca, México.

*Corresponding author:

26 Manuel Elías-Gutiérrez

27 melias@ecosur.mx

\section{Abstract}


34 Background. Holothuriophilus trapeziformis Nauck, 1880 is a holothurian-dweller pinnotherid

35 crab representing one of the two species of the genus distributed along the Pacific coast of Mexico

36 and Chile, respectively. While the parasitic ecological interaction with its host is well established,

37 the morphology of the male remains unknown, and DNA information for the species is not

38 available. Furthermore, the only morphological trait separating both species of the genus is

39 subjective and corresponds to the presence or absence of a gap between the fingers of the chelae.

40 Our goal is to complete and clarify the taxonomic status of H. trapeziformis and describe the male

41 morphology with the use of the integrative taxonomy, providing additional characters to

42 differentiate this species.

43 Methods. We collected new biological material in the Pacific coast of Mexico including the

44 topotypes. We also reviewed material from national collections to integrate morphology (based on

45 a complete and detailed description and illustration of the species using light microscopy),

46 ecological data (based on the identification of the host and the place where it was located within

47 the host), and the mtCOI gene information (commonly known as DNA barcode) to differentiate

48 Holothuriophilus trapeziformis from other related crabs.

49 Results. This species presents marked sexual dimorphism only in the primary sexual characters.

50 For the first time we describe morphological variability of traditionally stable characters. In

51 addition to the gap between the fingers of the chelae, Holothuriophilus trapeziformis differs from

52 H. pacificus (Poeppig, 1836) by their ornamentation, the shape of the male abdomen, and the

53 gonopod. COI distance divergence was $>3 \%$ between both Holothuriophilus species forming a

54 clear clade. DNA barcoding indicates only one taxon, with a maximum divergence of $2.2 \%$. All

55 the specimens have the same Barcode Index Number (BIN; BOLD: ADE9974). All the hosts for

56 H. trapeziformis were identified as Holothuria (Halodeima) inornata Semper, 1868; the presence 
57 of the crab in the host's coelomic cavity was confirmed, and for the first time we found it within

58 the intestine. The geographical distribution is the Pacific coast of Mexico. Based on the data

59 presented here, the taxonomic status of Holothuriophilus trapeziformis is now complete.

60 Introduction.

61 Pinnotherids (Crustacea: Pinnotheridae) are true decapod crabs, which show conspicuous sexual 62 dimorphism, notably different morphological stages of development and complex ecological 63 relationships with different invertebrates, however, they can also be found freeliving (Schmitt, 64 McCain \& Davidson 1973; Ocampo et al. 2011; Becker \& Türkay 2017). Worldwide, sixteen 65 species are known to be endobiontic with sea cucumbers ( $\mathrm{Ng} \&$ Manning 2003). Of these, only 66 two have been recorded on the Pacific coast of America and they are: Holothuriophilus 67 trapeziformis Nauck, 1880 (type locality in Mazatlan, Mexico, associated with the sea cucumber 68 Holothuria (Halodeima) inornata Semper,1868), and H. pacificus (Poeppig, 1836) (from 69 Talcahuano, Chile, associated with Athyonidium chilensis (Semper, 1868)) (Garth 1957; Manning 70 1993; Honey-Escandón \& Solís-Marín 2018). Holothuriophilus (Nauck, 1880) is diagnosed by its 71 transversally elongated carapace, wider anterior to middle portion; its short, robust and compressed 72 walking legs, with the dorsal margin crested; and the third maxilliped with the ischiomerus 73 indistinguishably fused (Garth 1957; Manning1993; Ng \& Manning 2003; Campos, Peláez-Zárate 74 \& Solís-Marín 2012).

75 The taxonomic status of $H$. trapeziformis remains incomplete, because male morphology is 76 unknown and the available information from female illustrations shows some inconsistencies when 77 the carapace, Mxp3 shape, and setae patterns are compared (see Bürger 1985: 380-381, pl. 9, fig. 78 26; Ahyong \& Ng 2007: 214, Figs. 20A, C; Campos, Peláez-Zárate \& Solís-Marín 2012: 60, figs. 
79 2B, C). Additionally, Holothuriophilus trapeziformis and H. pacificus only differ in a gap when

80 the fingers of the chelae closed in the latter (Campos, Peláez-Zárate \& Solís-Marín 2012).

81 Nauck's (1880) description of Holothuriophilus trapeziformis was brief, a holotype was not

82 designed and the identity of the type host was misidentified. Moreover, the female syntypes

83 deteriorated over time (Bürger 1895; De Man 1887; Ng \& Manning 2003). Later, Manning

84 (1993), Ng \& Manning (2003), and Ahyong \& Ng (2007) examined, described and illustrated the

85 syntype series to complete the diagnosis and designated a lectotype. However, there are

86 inconsistencies between their illustrations and the diagnostic characters are not informative with

87 the information available for Holothuriophilus pacificus.

88 For 84 years there were no new records of $H$. trapeziformis until Caso $(1958,1964,1965)$

89 reported four pinnotherids, determined as Pinnixa barnharti (not Pinnixa barnharti Rathbun,

90 1918), associated with Holothuria inornata Semper and H. kefersteinii (Selenka) (= H. riojai

91 Caso, 1964).

92 Thirty-four years later, Campos, Díaz \& Gamboa-Contreras (1998) determined as

93 Holothuriophilus sp. the specimens of Caso (1964). More recently Campos, Peláez-Zárate \&

94 Solís-Marín (2012) reviewed the genus and updated the species diagnosis. Finally, Honey-

95 Escandón \& Solís-Marín (2018) confirmed the ecological association between H. trapeziformis

96 and Holothuria inornata, but the specimens of Caso $(1958,1965)$ associated to Holothuria

97 kefersteinii remain uncertain because they have not been included in any of these documents and

98 their location is unknown (F Solís-Marín, 2018, pers. comm.).

99 For Holothuriophilus trapeziformis, there is currently no data on any gene, while for $H$.

100 pacificus, there is information related to the $\mathrm{COI}$ sequence for one specimen recovered from the

101 shoreline in southern Chile (CFAD062-11; boldsystems.org). Within this context, sequencing of 
102 approximately 650 bp region of the mitochondrial Cytocrome Oxidase 1 gene (COI) has been

103 promoted to conform a standardized DNA barcode system with the aim of being one more tool

104 for the identification of biological species with many applications in diverse fields of knowledge

105 (Hebert et al. 2003; Hajibabaei et al. 2007). Despite the fact that the acceptance to work with a

106 single molecular marker as a precise character to define a species was discussed (Will \&

107 Rubinoff 2004), nowadays it is considered that the COI marker is the best for decapod

108 identification (Spielmann et al. 2019). The utility of DNA Barcoding (COI sequence) has been

109 useful to delimit species of pinnotherids (Ocampo et al. 2013; Perez-Miguel et al. 2019),

110 brachyuran larvae (Brandão, Freire \& Bruton 2016) and other crustaceans (Costa et al. 2007;

111 Matzen da Silva et al. 2011).

112 Therefore, the goal of this study is to review the taxonomy of Holothuriophilus trapeziformis by

113 describing the male, examining the morphological variability in both sexes, updating the range of

114 distribution, and establishing a baseline of mitochondrial COI gene barcode. Finally, with this

115 information, we propose new diagnostic characters that will allow better identification of the two

116 species of Holothuriophilus known in the Pacific coast of America.

\section{Material \& methods}

\section{Morphology}

119 Fifty-five crabs belonging to Holothuriophilus trapeziformis were extracted from the coelom and

120 intestine of the sea cucumber Holothuria (Halodeima) inornata. These were collected in 11

121 locations from the Pacific coast of Mexico (Fig. 1). These localities were grouped into two

122 arbitrary regions designated as the northern region (Sinaloa state; which include the type locality

123 Mazatlan) and the southern region (Guerrero and Oaxaca states). Hosts were manually collected

124 through skin and SCUBA diving at a maximum depth of 10 meters. The collected material was 
125 labeled and fixed according to Elías-Gutiérrez et al. (2018) protocol for tissue preservation and

126 DNA analyses. Due to the size of the specimens and the thickness of the cuticle, we injected

127 ethanol into the body through the joints of the appendices with insulin syringes.

128 All biological material (Table S1) was classified and deposited in the Scientific Collection of

129 Marine Invertebrates of the Laboratorio de Sistemática de Invertebrados Marinos (LABSIM) at

130 Universidad del Mar (UMAR), Oaxaca, Mexico (OAX-CC-249-11). Hosts were identified with

131 specialized literature (Solís-Marín et al. 2009; Honey-Escandón \& Solís-Marín 2018).

132 For the analysis of the taxonomic status of Holothuriophilus trapeziformis specialized literature

133 from Nauck (1880), Manning (1993), Ng \& Manning (2003), Ahyong \& Ng (2007), and

134 Campos, Peláez-Zárate \& Solís-Marín (2012) was reviewed. Likewise, for H. pacificus, Poeppig

135 (1836), Nobili (1901), Rathbun (1918), and Garth (1957) were reviewed.

136 The species description follows the terminology of Manning (1993). We consider the gonopod

137 terminology as first gonopod and second gonopod of the male, according to Becker, Türkay \&

138 Brandis (2012). The setae terminology is based on Garm \& Watling (2013). Drawings were

139 made with the help of a camera lucida and then digitalized in a vector format. Pictures were

140 taken with a Nikon D5100 digital camera. Measurements are given in millimeters and latitude

141 and longitude were obtained from Google Earth ${ }^{\mathrm{TM}}$.

142 Because we were only able to obtain eight specimens (three males and five females) from the

143 northern region (Pinitos Beach in the type locality Mazatlan, Sinaloa, Mexico), in contrast to 47

144 (six males and 41 females) from localities in the southern region, and due to morphological

145 variability observed between these two regions, it was necessary to standardize the observations

146 by using specimens in the same stage of development. Eight millimeters carapace width was the

147 common size in both, the northern and southern regions, in males and adult ovigerous females. 
148 This size-group was used to illustrate (Figs. 5 and 6) and discuss the observed morphological

149 variability. The specimen and the dissected appendages were mounted on a plastic clay base for

150 standardizing the observations, and to make the drawings. For the carapace contour, the samples

151 were mounted, so the dorsal view of the posterior margin line of the carapace was observed. For

152 the Mxp3, we extracted it from its base to obtain both endopod and exopod and to mount it with

153 the articles in the same perspective. The cutting edge of the fingers' chelae was cleaned of dirt to

154 see all the teeth. The first gonopod was extracted from its base, and the setae cleaned of dirt.

155 Abbreviations used in the text: $\mathrm{CL}$, carapace length (taken as the middle line from the frontal

156 margin to the posterior margin of the carapace); $\mathrm{CW}$, carapace width (measured in its medium-

157 anterior portion); Mxp2, second maxilliped; Mxp3, third maxilliped; WL, walking legs 1 to 4

158 (thoracopods 2-5).

\section{DNA extraction and PCR amplification}

160 Genomic DNA of individuals of Holothuriophilus trapeziformis was extracted from biological

161 material collected in the field and some individuals from the OAX-CC-249-11 regional

162 collection of the UMAR, using tissue from the walking legs, the chelae, or eggs from the

163 ovigerous females. Tissues were placed into 96-well microplates with a drop of $96 \%$ ethanol, and

164 DNA extraction was carried out following the standard glass fiber method consisting of a mix of

165 Proteinase K with an invertebrate lysis buffer according to Ivanova, De Waard \& Hebert (2006).

166 Following the DNA extraction, the PCR mixture with a final volume of $12.5 \mu 1$ contained $2 \mu \mathrm{l}$ of

167 Hyclone ultrapure water (Thermo Fisher Scientific), $6.25 \mu 1$ of 10\% trehalose (previously

168 prepared: $5 \mathrm{~g} \mathrm{D}-(+)$ - trehalose dihydrate (Fluka Analytical) in a total of $50 \mathrm{ml}$ of molecular grade

$169 \mathrm{ddH} 2 \mathrm{O}$ ), $1.25 \mu \mathrm{l}$ of 10X PCR Platinum Taq buffer (Invitrogen), $0.625 \mu \mathrm{l}$ of $50 \mu \mathrm{mol} / \mathrm{L} \mathrm{MgCl} 2$

170 (Invitrogen), $0.0625 \mu \mathrm{l}$ of $10 \mu \mathrm{mol} / \mathrm{L}$ dNTP (KAPA Biosystems), $0.125 \mu \mathrm{l}$ of each $10 \mu \mathrm{mol} / \mathrm{L}$ 
171 primer, $0.06 \mu 1$ of PlatinumTaq DNA polymerase (Invitrogen), and $2 \mu 1$ of DNA template. All

172 specimens were amplified with the Zooplankton primers (ZplankF1_t1 and ZplankR1_t1, see

173 Prosser, Martínez-Arce \& Elías-Gutiérrez 2013 for details). The reactions were cycled at $94^{\circ} \mathrm{C}$

174 for $1 \mathrm{~min}$, followed by five cycles of $94^{\circ} \mathrm{C}$ for 40 seconds, $45^{\circ} \mathrm{C}$ for 40 seconds and $72^{\circ} \mathrm{C}$ for 1

$175 \mathrm{~min}$, followed by 35 cycles of $94^{\circ} \mathrm{C}$ for 40 seconds, $51^{\circ} \mathrm{C}$ for 40 seconds and $72^{\circ} \mathrm{C}$ for $1 \mathrm{~min}$,

176 with a final extension of $72^{\circ} \mathrm{C}$ for $5 \mathrm{~min}$. PCR products were visualized on a pre-cast $2 \%$ agarose

177 gels (E-Gel ${ }^{\odot} 96$ Invitrogen), and the most intense positive products were selected for sequencing.

178 Sequencing and DNA barcode

179 Selected PCR products were sequenced using a modified (Hajibabaei et al. 2005) BigDye ${ }^{\odot}$

180 Terminator v.3.1 Cycle Sequencing Kit (Applied Biosystem, Inc.), and then sequenced

181 bidirectionally on an ABI 3730XL automated capillary sequencer using M13F and M13R

182 sequence primers at the Biology Institute at the National Autonomous University of Mexico and

183 at the Eurofins Genomics Louisville Laboratory. Sequences were edited using CodonCode ${ }^{\odot} \mathrm{v}$

184 3.0.1 (CodonCode Corporation, Dedham, MA, USA) and uploaded to BOLD. In some cases, the

185 original forward and reverse trace files uploaded to BOLD were checked again, consensus

186 assembly was generated, and edited manually with Sequencher ${ }^{\odot}$ 4.1.4. (Gene Codes Corporation,

187 Ann Arbor, MI, USA), and then they were aligned using BioEdit ${ }^{\odot}$ (Hall 1999).

188 Likelihood tree and distance analysis

189 COI sequences generated for Holothuriophilus trapeziformis in this study were compared with

190 COI sequences from other pinnotherids collected in the Eastern Pacific coast of America,

191 available in BOLD and/or GeneBank (Table S2). Sequence data, trace files, and primer details

192 for all $H$. trapeziformis specimens and for the outgroup species are available under the dataset

193 name "Holothuriophilus trapeziformis from Mexico" (DOI: dx.doi.org/10.5883/DS- 
194 PINMX1HT) in the Barcode of Life Data System (barcodinglife.org). Additionally, $H$.

195 trapeziformis sequences were uploaded to GenBank (https://www.ncbi.nlm.nih.gov/genbank/).

196 Accession numbers are noted in table S2.

197 We calculated the best-fitting evolution model of nucleotide substitution for distance based on

198 COI alignments for the Maximum Likelihood (ML) tree accordingly to the Akaike (AIC) and

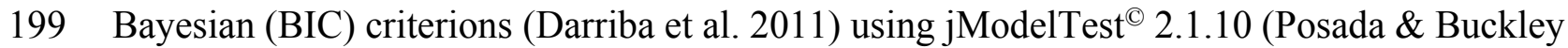

200 2004). The final tree was estimated with 1000 bootstrap replicates in MEGA $^{\odot} 7.0$ (Tamura et al.

201 2013). With the compress/expand feature of MEGA we prepared the final tree. Also, we

202 estimated the interspecific COI genetic distances for the dataset using the Kimura-2 parameters

203 distance method in MEGA. Values greater than 3\% were considered the threshold for the

204 delimitation of the species (Hebert et al. 2003).

205 Acronyms used in the text: BOLD, barcode of life database (boldsystems.org); BIN, barcode

206 index number (sensu Ratnasingham \& Hebert 2013); BOLD-ID, Specimen ID in the Barcode of

207 Life Data System; CNE-ICML-UNAM, National Collection of Echinoderms of the Institute of

208 Marine Sciences and Limnology of the National Autonomous University of Mexico; DC-NHM,

209 Division of Crustacea, Natural History Museum, Smithsonian Institution; SMF-ZMG,

210 Senckenberg Museum für Naturkunde, Zoologisches Museum Göttingen University, Humboldt

211 Universität, Berlin; UABC, Autonomous University of Baja California, Mexico; UMAR,

212 Universidad del Mar campus Puerto Angel, Oaxaca, Mexico.

213 Collectors: AEV, Aidé Egremy Valdés; AGF, Andrea Glockner Fagetti; CCA, Carlos Cruz

214 Antonio; AHM, Adanely Hernández Muñoz; FBV, Francisco Benítez Villalobos; FCC, Fernando

215 Cortés Carrasco; HMC, Humberto Mesa Castillo; KFL, Karen Lizbeth Flores López; KMB,

216 Karen Mesa Buendía; RGF, Rebeca Granja Fernández; VCH, Valeria Chavez García. 
217 For this study, we obtained a field collecting permit for non-commercial scientific research

218 purposes from Secretaría de Agricultura, Ganadería, Desarrollo Rural, Pesca y Alimentación

219 (SAGARPA) and Comisión Nacional de Acuacultura y Pesca (CONAPESCA) (Collecting

220 permit: PPF/DGOPA-301/17).

221 Results

222 We analyzed the morphology of 55 specimens (Supplemental Table S1) from two coastal regions 223 (northern and southern) in the Mexican Pacific (Fig. 1). Notable variations were determined after

224 detailed morphological examination of the specimens. . In particular, the morphology of the 225 topotypes (northern region; Fig. 1A) shows variation in the general carapace shape outline and 226 general appearance which looks stouter and eroded in contrast to that of the southern region.

227 Nevertheless, in all the specimens we observed diagnostic characters of the species as the 228 subrectangular carapace shape, with its crested lateral margin, the compressed walking legs, and 229 the gap between the fingers of the chelae. Also, the male first and second gonopods plus the 230 DNA data, confirm that all material examined corresponds with Holothuriophilus trapeziformis.

231 Systematics

232 Infraorder Brachyura Latreille, 1802

233 Family Pinnotheridae De Haan, 1833

234 Genus Holothuriophilus Nauck, 1880

235 Diagnosis (modified from Manning 1993). Carapace broader than longer, widest on mid anterior 236 portion, transversely subcuadrangular, subrectangular, subovate or subtrapezoidal. Third

237 maxilliped with ischium and merus fused, no suture line; exopod with one flagellar segment;

238 palp with 3-segments; propodus conical, shorter than carpus, subspatuliform dactyl, articulated at 
239 basal of propodus, extending beyond end of propodus. Dactylus of walking legs short, similar

240 and subequal. Abdomen of seven segments in both sexes.

241 Holothuriophilus trapeziformis Nauck, 1880

242 (Figs. 2A-G, 3A-D, 4A-K, 5A-K, 6A-D)

243 Holothuriophilus trapeziformis Nauck, 1880: 24, 66 [ovigerous female type]. —De Man 1887:

$244721-722$ [female $(\mathrm{CW}=13.8 \mathrm{~mm}, \mathrm{CL}=10.5 \mathrm{~mm})]$. — Manning 1993: 524-528, Fig. 3c

245 [resurrected to Holothuriophilus]. — Ng \& Manning 2003: 903, 916-918, Fig. 7C-F [designated

246 female lectotype $(\mathrm{CW}=7.7 \mathrm{~mm}, \mathrm{LC}=4.8 \mathrm{~mm})$ : SMF-ZMG 67/565a]. —Ahyong \& $\mathrm{Ng} 2007$ :

247 213-214, Fig. 20 [redescribed and refigured]. —Campos, Peláez-Zárate \& Solís-Marín 2012: 57-

248 62, Figs. 1A, B, 2A-D [female $(\mathrm{CW}=9.1 \mathrm{~mm}, \mathrm{CL}=5.5 \mathrm{~mm})]$.

249 Pinnotheres trapeziformis. - Bürger 1895: 380-381, plate 9, Fig. 26, plate 10, Fig. 25 [female

250 type $(\mathrm{CW}=14 \mathrm{~mm}, \mathrm{CL}=10 \mathrm{~mm})$, male $(\mathrm{CW}=5 \mathrm{~mm}, \mathrm{CL}=8.5 \mathrm{~mm})]$. -Adensamer 1897: 107.

251 -Schmitt, McCain \& Davidson 1973: 5, 13, 89 [list].

252 Pinnoteres trapeziformis Balss 1957: 1417 [not 1956 fide Schmitt, McCain \& Davidson 1973].

253 Pinnixa barnharti (no Rathbun, 1918) Caso 1958: 329; 1965: 254-26.

254 Holothuriophilus sp. Campos, Díaz \& Gamboa-Contreras 1998: 377, Fig. 1E.

255 Material examined: 56 specimens: 25 ovigerous females, 22 females, nine males (Table S1).

256 General distribution: Tropical Mexican Pacific.

257 Previous records: Mazatlan, Punta Tiburón (Sinaloa); Ixtapa (Guerrero).

258 New records: Pinitos Beach (Sinaloa); Nudista Beach, Zacatoso Beach, Caleta de Chón Beach

259 (Guerrero); Agua Blanca Beach, Coral Beach, Camarón Beach, Panteón Beach, Estacahuite

260 Beach, La Tijera Beach, San Agustín Beach, El Tejón Beach (Oaxaca).

261 BIN: BOLD:ADE9974 
262 Carapace size (mm): See Supplemental Table S1.

263 Diagnosis. Carapace transversely subrectangular, suboval or subtrapezoidal. Crestated

264 anterolateral margin, a hepatic notch with a blunt tooth inside. Inner surface of merus and carpus

265 of chelipeds densely setose; ventral inner margin of the propodus with a row of short setae,

266 without a gap when the cutting edge of propodus and dactylus meet; cutting edge of the dactylus

267 with proximal denticles, a conspicuous medial tooth, and a distal convex or acute projection.

268 Dorsal surface of the merus of WL1, WL 3 and WL 4 with setae, WL2 without seta. Abdomen

269 with 6 somites plus free telson; on male, margin of somite 4 to 6 concave, telson subrounded.

270 First gonopod notably curved outward from its mid-distal portion. 
271 Description: Male (Fig 2A-C; UMAR-DECA-308; CW = 11 mm, CL = 7 mm): Carapace,

272 transversely subtrapezoidal, wider than long, CW/CL ratio ca. 1.6, mid-anterior portion widest;

273 anterolateral margins slightly projected, crested, a hepatic notch with a blunt middle tooth (Figs.

274 3A, B; bold arrow); dorsal surface convex, smooth, undefined regions; mid-posterior and

275 posterolateral surface with microscopic pits with variable pilosity and size (Figs. 3A); inferior

276 lateral margin of the carapace with abundant plumose setae (Fig. 3A).

277 Front bilobed, scarcely visible in dorsal view, margin granulated, surface slightly pubescent (Fig. 278 3B).

279 Orbits small; eyes pigmented, same size as the orbits; ocular peduncle scarcely pubescent.

280 Antennules robust; peduncle with two segments, biflagellate, transversely folded inside fossae;

281 upper flagellum with two articles, second article the longest and sharpened distally with apical

282 setae (Fig. 4Ba); lower flagellum conic with four articles decreasing in size, the first three

283 articles with a transverse line of simple setae, fourth article with two transverse lines of simple

284 seta (Fig. 4Bb).

285 Antennae long, slender, with 12 articles, last article with short apical setae (Fig. 4A).

286 Pterygostomian region pubescence (Fig. 3B). Buccal frame trapezoidal, completely covered by

287 Mxp3. Mxp2 endopod with five articles, with setae (Fig. 4Ca), dactylus subrounded and shorter 288 than propodus (Fig. 4C); exopod with an article, wider distally, external surface with an elevated 289 ridge (Fig. 4Cb), flagellum with long apical setae (Fig. 4Cc), epipodite long, distal margin 290 rounded (Fig. 4Cd). Mxp3 ischiomerus fused without suture line, width/length ratio 0.7, mesial 291 margin convex with setae, medial margin with a conspicuous projection (Fig. 4Da); carpus

292 subconical, with short setae; propodus subconical (Fig. 4Dc); subspatuliform dactyl, widens

293 distally (Fig. 4D), exceeds the length of the propodus, external surface with short plumose setae, 
294 external margin with long plumose setae; exopod with one article and a flagellum, external

295 margin and external surface with short simple setae, slender flagellum, with plumose long setae

296 (Fig. 4E).

297 Third sternal plate with anterior margin sinuous, anterolateral angles with crenulated margin

298 (Fig. 3C), surface scarcely pilose (Fig. 3C); fourth plate slightly globose, surface with

299 microscopic pits (Fig. 3C), anteroexternal angle curved outward, with margin crenulated (Fig.

$3003 \mathrm{C})$.

301 Chelipeds subequal (Fig. 2A); external and lower surface of merus and lower margin of carpus

302 with plumose setae (Figs 2B); chelae wide with ventral margin microscopically granulated (Fig.

303 4F, 7C), dorsal margin slightly crested and bent inwards; fingers wider than longer, spooned with

304 acute tip subdistally (Fig. 4F), without a gap where the cutting edge of propodus and dactyl meet

305 (Fig. 7C). Movable finger shorter than fixed finger, crossed inward when closed. Movable

306 fingers of both chelae with cutting edge sinuous, three medial teeth (Fig. 4F) and a subdistal

307 convex projection (Fig. 4F). Fixed finger cutting edge of both chelae with nine teeth and

308 subdistal surface flatted (Fig. 4F), ventral margin with short setae.

309 Walking legs similar in both sides of the body, relative length WL3 > WL2>WL1>WL4,

310 segments short, robust, compressed and dorsal margin crested, ventral surface with plumose

311 setae; dorsal margin of merus of the WL1, WL3, WL4 with plumose setae, and WL2 naked;

312 dactylus with acute tips, curved, and stout; length of the dactylus subequal to propodus of the

313 WL1-WL3, and WL4 shorter than propodus (Fig. 3A).

314 Abdomen symmetrical, subtriangular, six free somites and telson margin with short setae, lateral

315 margin from somites 4-6 slightly concave and narrowing, telson subrounded (Figs. 3D). 
316 First gonopod slender, margins sinuous, mid-distal portion notably curved outwards, surface with

317 abundant plumose setae (Fig. 3E). Second gonopod small, slightly bent inwards, tip pointing

318 upwards, distal margins convex with shallow notch (Fig. 3F).

319 Female (Figs. 2D-F; UMAR-DECA-307; CW = 10.50, CL = 7): Same as the male but with

320 less abundant setae in the pterygostomian region and ventral margin of the chelae; dorsal surface

321 of the merus of the WL1-4 and inner surface of the merus and carpus of the cheliped with long

322 and abundant setae. Carapace slightly more convex. Abdomen subovate. See variation section

323 for more details.

324 Color in life: Body beige or creamy white, dorsal surface of carapace and chelipeds carpus, and

325 on the external surface of the chelae with red patches. In fixed and preserved specimens this

326 pattern of color remains, or it could change from red to light or dark brown (Fig. 2A-F).

327 Habitat: Marine. Associated with the sea cucumber Holothuria (Halodeima) inornata, living in

328 its coelom and inside its intestine (Fig. 2G). This holothurian inhabits rocky-sand sea floor in

329 shallow waters $(0-18 \mathrm{~m})$.

330 Variation: Morphological variation observed between the $8 \mathrm{~mm}$ individuals from the two

331 regions (northern and southern) showed three general carapace shapes : subrectangular, suboval

332 and subtrapezoidal.

333 The subrectangular carapace (Figs. 5A, 6A) was observed in $33 \%$ of the males and in $11 \%$ of

334 females (three and five specimens, from the northern region). It has projected and straight margin

335 frontal lobes, and straight anterolateral margin with a deep hepatic notch, eroded, and extended

336 over the carapace (Fig 5A) in males but in females it is less conspicuous (Fig. 6A). Males have

337 truncated and scarcely projected anterolateral margins in which the anterior portion is concave

338 (Fig. 5A) compared to straight in the females (Fig. 4A). 
339 The subovate carapace (Figs. 5E, I, 6D, G) was observed in $56 \%$ of the males and in $85 \%$ of

340 females (five and 40 specimens from the southern region). It has oblique and scarcely projected

341 frontal lobes; anterolateral margin continues smoothly to the lateral margin forming a convex

342 lobe (Figs. 5E, I), the hepatic notch in the males is deep, eroded and extended (Fig. 5E, I), while

343 in the females is shallow, slightly eroded, and less extended over the carapace (Figs. 6D, G).

344 The subtrapezoidal carapace (Fig. 2D, 7A) is present in $11 \%$ of the males and in $2 \%$ of females

345 (one and two specimens from the southern region). It has scarcely projected frontal lobes,

346 oblique and straight anterolateral margin ending lateral lobes.

347 Regardless of the carapace shape, the females have a more convex shell and margin of the frontal

348 lobes and the eyes are not visible in dorsal view, and only a slight hepatic notch can be seen

349 (Figs. 6A, D, G). This shape was more frequent in ovigerous females (ten specimens, 67\%) than

350 in non-ovigerous (five specimens, 33\%).

351 Despite the variation in the carapace shape of both sexes, all the ratios (v.g. CW/CL ratio, length

352 between the notch of the frontal lobes to the external orbital angle, length between the external

353 orbital angle to the anterolateral angle, ishiomerus width/length ratio of the Mxp3) were

354 constant.

355 Regardless of the shape of the carapace, the Mxp3 features show very subtle variations resulting

356 from mounting and drawing. However, the observed variations are: The ischiomerus inner

357 margin has a blunt or slightly acute projection (Figs. $5 \mathrm{Ca}, 5 \mathrm{Ga}, 5 \mathrm{Ka}, 6 \mathrm{Ca}, 6 \mathrm{Fa}, 6 \mathrm{Ia}$ ). The dorsal

358 margin of the carpus from convex (Figs. $5 \mathrm{~Kb}, 6 \mathrm{Cb}, 6 \mathrm{Fb}, 6 \mathrm{Ib}$ ) to straight (Figs.5Cb, 5Gb).

359 Distally expanded subspatulated dactylus (Figs. 5Kd, 6Cd) or narrower suboblong one (Figs. 5

$360 \mathrm{Cd}, 5 \mathrm{Gd}, 6 \mathrm{Fd}, 6 \mathrm{Id})$. However, in all cases there is a projected ridge on the internal surface of the 
361 carpus with setae, and the distal margin of dactylus slightly overreaches the propodus (Figs. 5Cd,

$362 \mathrm{Gd}, \mathrm{Kd}, 6 \mathrm{Cd}, \mathrm{Fd}, \mathrm{Id})$.

363 The chelae fingers ornamentation is most variable and does not show a relationship with

364 carapace shape or size. In both sexes the cutting edge of the movable finger has two or three

365 proximal teeth (Figs. 5B, 5F, 5J, 6B, 6E, 6H). These teeth could be blunt or acute, but in the

366 females, they always are acute. The medial tooth in males could be simple (Figs. 5B, J) or

367 bicuspid (Fig. 5F), but in females it is always simple (Figs. 6B, E, H). The subdistal projection in

368 both sexes can be blunt (Figs. 5B, 5J, $6 \mathrm{~B}, 6 \mathrm{H}$ ) or acute (Figs. 5F, 6E). The cutting edge of the

369 fixed finger is more variable between sexes. In males it has six to nine proximal teeth (Figs. 5B,

$370 \mathrm{~F}, \mathrm{~J}$ ), but in females it has four to thirteen (Figs. 6B, E, H). In males it has one middle tooth

371 which is always bicuspid (Figs. 5B, F, J) but in females could be bicuspid (Figs. 6B, E) or simple

372 (Fig. 6H). Only one specimen (DECA-1172) had different sized chelae and a different teething

373 pattern on the cutting edge of the fixed finger (Fig. 6J, K).

374 The first gonopod is related to the carapace shape. In caudal view it is similar between males of

375 the northern region with a subrectangular carapace and that of the southern region of Oaxaca

376 with suboavate and subtrapezoidal carapace. In these, the external and internal margins are

377 sinuous (Figs. 5D, L), the curvature degree is approximately $90^{\circ}$ (Fig. 5D) and $75^{\circ}$ (Fig. 5L).

378 The tip of the external margin is truncated (Figs. 5De-f, Le-f), and the ventral margin of the tip

379 has a blunt projection (Figs. 5De, Le).

380 Instead, other males from Guerrero, in the southern regions, with a subovate carapace, have the

381 external and internal margins of the first gonopod less sinuous and the curvature degree is

382 approximately $65^{\circ}$ (Fig. $5 \mathrm{H}$ ). The tip of the external margin is convex (Fig. 5He-f), and the

383 ventral margin of the tip has an acute projection (Fig. $5 \mathrm{He}$ ). 
384 Remarks: The taxonomic history of Holothuriophilus trapeziformis was synthetized by Campos,

385 Peláez-Zárate \& Solís-Marín (2012), and they highlighted the fact that the specimen identified by

386 Bürger (1895) as a male based on the shape of the abdomen is actually a female. We observed

387 the same situation in several young individuals. The presence of pleopods in all of the abdominal

388 somites confirms that they are also females. In juvenile males the lateral margins of the abdomen

389 are straight instead of concave and the first and second gonopods are present. This finding allows

390 us to present the complete male morphology of H. trapeziformis.

391 All the biological material examined shows phenotypic variation, particularly between the

392 individuals from the type locality in Mazatlan (northern region) with respect to those from of

393 Guerrero and Oaxaca (southern region), but COI gene shows no differences.

394 With our detailed description of the male morphology, it is now possible to differentiate

395 Holothuriophilus trapeziformis from H. pacificus with certainty by the carapace shape and

$396 \mathrm{CW} / \mathrm{CL}$ ratio. In $H$. trapeziformis, it can be subrectangular (Fig. 5A, 6A; CW/CL = 1.6), suboval

397 (Fig. 5E, I, 6D, G; CW/CL = 1.6) or subtrapezoidal (Fig. 1A, D, 2A, 7A; CW/CL = 1.6), while

398 in H. pacificus it is subcuadrangular (Fig. 7E; CW/CL = 1.2).

399 Nevertheless, the mxp3 does not present differences between both species, except for the

400 flagellum of the exopod that according to the illustrations is robust (Figs. 7B, J, K, 8A) in $H$.

401 trapeziformis, and slender in H. pacificus (Figs. 7F, 8D).

402 The abdomen of Holothuriophilus trapeziformis is subtriangular in males, with lateral margins

403 narrowing from the fourth to the sixth somite. The third somite has convex lateral margins. The

404 sixth somite has concave lateral margins, and the telson is subrounded and wider than long (Fig.

405 8B). In H. pacificus, it is triangular, the lateral margins are almost straight. The third and sixth 
406 somite lateral margins are concave, and the telson is subtriangular and more extended than wide 407 (Fig. 8E).

408 In the case of adult ovigerous and non-ovigerous females of Holothuriophilus trapeziformis, the 409 abdomen is suboval and wider than long. The first somite has convex lateral margins. The 410 second somite has sinuous distal margins. The third somite has oblique and downward lateral

411 margins. The sixth somite has oblique and outward lateral margins, and the telson has a length to 412 width ratio ca. 0.2 (Fig. 7D). In contrast, in H. pacificus it is suboval and longer than wide. The

413 first somite has concave lateral margins. The second somite has almost straight distal margins.

414 The third somite has oblique and upwards lateral margins. The sixth somite has convex lateral 415 margins, and the telson has a length to width ratio ca. 0.3 (Fig. $7 \mathrm{H})$.

416 The first gonopod of Holothuriophilus trapeziformis has a sinuous lateral margin with a larger 417 distal portion curved outwards, with abundant setae (Fig. 8C). In H. pacificus it is straight, with 418 the distal portion slightly curved outwards, and less setae (Fig. 8F).

419 Distribution and ecological comments: With this study we increased the previous known 420 distribution range that went from Punta Tiburón (Sinaloa state) to Playa Tejón (Oaxaca state).

421 We found crabs in the coelom cavity and near the cloaca of the host, as mentioned by Manning 422 (1993), Campos, Peláez-Zárate \& Solís-Marín (2012), and Honey-Escandón \& Solís-Marín 423 (2018). For the first time, we found the crab within the intestine (Fig. 1G).

424 Holothuria (Halodeima) inornata is distributed throughout the Tropical Eastern Pacific from the 425 Gulf of California, Mexico to Ecuador, and in the temperate island Lobos de Afuera, Peru 426 (Prieto-Rios et al. 2014; Honey-Escandón \& Solís-Marín 2018). It also represents an important 427 fishery resource throughout its distribution range (Santos-Beltrán \& Salazar-Silva 2011). There 428 are no records for Holothuriophilus trapeziformis outside the Pacific coast of Mexico. 


\section{DNA Barcodes}

430 From the 56 crabs examined (Table S1), 51 were processed. The number of base pairs was

431 between 549 bp and 648 bp for 37 specimens with a sole Barcode Index Number (BIN;

432 Ratnasingham \& Hebert 2013) in the BOLD database: ADE9974. Of those, 35 produced high

433 quality barcodes. The 14 crabs that could not be amplified correspond to old museum material

434 and recent collections that were not fixed according to the Elías-Gutiérrez et al. (2018) protocol.

435 A BLAST query in GenBank confirmed our sequences to belong to a brachyuran lineage.

436 Maximum likelihood tree and genetic distance analysis

437 The best nucleotide substitution model according to the AIC and BIC criterion was General Time

438 Reversible under a gamma distribution $(\mathrm{GTR}+\mathrm{G})$ model (Nei \& Kumar 2000). The Maximum-

439 Likelihood (ML) distance method under the selected model delimited the 37 sequences of

440 Holothuriophilus trapeziformis from the dataset (DS-PINMX1HT) in a single cluster. The cluster

441 of $H$. trapeziformis is well separated from $H$. pacificus as shown in figure 9 , with a 12 to $14 \%$

442 divergence among all specimens. Holothuriophilus is also close to the Calyptraeotheres clade,

443 but far from other species (Fig. 9) with an interspecific divergence ranging from 12 to 19\%. The

444 intraspecific divergences in $H$. trapeziformis ranged from 0 to $2.2 \%$. This result is congruent

445 with the BOLD distance summary analyses, which shows an average distance of $0.73 \%$ and a

446 maximum of $2.27 \%$ for sequences with more than $500 \mathrm{bp}$.

\section{Discussion}

448 A crucial problem for traditional taxonomy based solely on morphology, is the variability of the

449 phenotype of decapods. In pinnotherid taxonomy, a crucial goal is to provide a complete

450 description of the species with detailed illustrations of common and unusual structures for

451 comparative purposes (Derby \& Antema 1980; Ahyong, Komai \& Watanabe 2012; Salgado- 
452 Barragán 2015). In that regard, characters previously not described like the antenna, the

453 antennule, the Mxp2, and the second male gonopod show no differences between all the material

454 examined, despite the variations noted above. These variations are greater when comparing

455 individuals from the northern region of Mexico (which include the topotype in Mazatlan, Sinaloa

456 state) to those from the southern region (Guerrero and Oaxaca states). However, COI data

457 analysis confirms all the material examined corresponds to the same species based on the

458 thresholds to delimitate species proposed by Hebert et al. (2003) and Lefébure et al. (2006).

459 Phenotype variation is the result of a plastic response to different environmental pressures

460 (Hurtado, Mateos \& Santamaria 2010; Rossi \& Mantelatto 2013) or due to recent or historical

461 processes that limit the flow of genes because of environmental barriers (Wares, Gaines \&

462 Cunningham 2001; Avise 2009). Despite the fact that these processes are well documented, in

463 the case of brachyuran crabs, there is evidence showing that it does not occur in grapsids

464 (Cassone \& Boulding 2006), ocypodids (Laurenzano, Mantelato \& Schubart 2013), pinnotherids

465 (Ocampo et al. 2013), sesarmids (Zhou et al. 2015), and varunids (Zhang et al. 2017). However,

466 for pinnotherids, the several long-lasting growth phases require a specific host or a variety of

467 hosts to complete them (Bousquette 1980; Hamel, Ng \& Mercier 1999; Ocampo et al. 2011) and

468 represent another drawback. Nevertheless, it allows them to maintain connectivity between

469 populations throughout their geographical distribution range (Haines, Edmunds \& Pewsey 1994;

470 Hamel, Ng \& Mercier 1999; Ocampo et al. 2012, 2013; Guilherme, Brustolin \& de Bueno 2015;

471 Becker \& Türkay 2017).

472 In the case of Holothuriophilus trapeziformis, it is considered a specific endobiontic parasite of

473 its host (Nauck 1880; Campos, Peláez-Zárate \& Solís-Marín 2012), resulting in possibly limited

474 connectivity through larval dispersal. In addition to the above, the particular oceanographic 
475 conditions known along the Pacific coast of Mexico and the distribution of the host (Hurtado et

476 al. 2007; Paz-García et al. 2012; Prieto-Rios et al. 2014; Gómez-Valdivia, Parés-Sierra \& Flores-

477 Morales 2015; Honey-Escandón \& Solís-Marín 2018), could explain the morphological

478 differences observed between the northern specimens compared to those of the south.

479 Currently, with the complete description of the male using the new characters described here, we 480 can conclude that Holothuriophilus trapeziformis is different from H. pacificus.

481 Regarding the DNA barcoding approach for the COI gene, in a difficult group to work with, we

482 were successful thanks to the injection of ethanol inside the body of the crabs through the joints

483 of the exoskeleton, and the use of semi-degenerate zooplankton primers (Prosser, Martínez-Arce

484 \& Elías-Gutiérrez 2013) instead of Folmer's (Mantelatto et al. 2016). We obtained the

485 amplification of $72 \%$ of the specimens and $69 \%$ sequencing success.

486 The resulting maximum likelihood tree allowed us to confirm Holothuriphilus trapeziformis as a

487 separate species, indicating a divergence from 12 to $14 \%$ against the closest taxa, H. pacificus.

488 Also, our tree agrees with Palacios-Theil, Cuesta \& Felder (2016) regarding the association of

489 the genus Holothuriophilus and Calyptraeotheres.

490 The taxonomic status of Holothuriophilus trapeziformis is now complete, based on the

491 morphology of both sexes, their distribution, specificity to a single host, and the DNA barcodes.

492 We believe that Holothuriophilus trapeziformis with its host reflects the restricted habitat in which

493 it lives and possibly the local environmental barriers in the Pacific coast of the American continent.

\section{Acknowledgements}

495 We are grateful to the Chetumal Node of the Mexican Barcode of Life (MEXBOLD) for their

496 support for the genetic analysis, in particular to Alma Estrella García-Morales who assisted with

497 the DNA process of the biological samples. J. Rolando Bastida-Zavala gave us access to the 
498 collection material of Laboratorio de Sistemática de Invertebrados Marinos (LABSIM) from

499 Universidad del Mar. Fernando Álvarez-Noguera and José Luis Villalobos-Hiriart provided

500 access to the collection material of the Colección Nacional de Crustáceos (CNCR) del Instituto

501 de Biología de la Universidad Nacional Autónoma de México. Virgilio António Pérez and staff

502 from Buceo Huatulco supported our field work. Miriam Steinitz-Kannan from Northern

503 Kentucky University kindly assisted us with the English edition of this manuscript.

504 References

505 Adensamer T. 1897. Revision der Pinnotheriden in der Sammlung des K. K. Naturhistorischen

506 Hofmuseums in Wien. Annalen des K.K. Naturhistorischen Hofmuseums 12:105-110.

507 Ahyong ST, Ng PKL. 2007. The pinnotherid type material of Semper (1880), Nauck (1880) and

508 Bürger (1895) (Crustacea: Decapoda: Brachyura). Raffles Bulletin of Zoology Supplement $16: 191-226$.

510 Ahyong ST, Komai T, Watanabe T. 2012. First Viridotheres Manning, 1996, from Japan, with

511 a key to the species (Decapoda, Brachyura, Pinnotheridae). In: Komatsu H, Okuno J,

512 Fukuoka K, eds. Studies on Eumalacostraca: A Homage to Masatsune Takeda,

513 Crustaceana Monographs 17:35-47 https://doi.org/10.1163/9789004202894_003

514 Avise JC. 2009. Phylogeography: retrospect and prospect. Journal of Biogeography 36:3-15

$515 \quad$ https://doi.org/10.1111/j.1365-2699.2008.02032.x

516 Balss H. 1957. Decapoda. In: Bronns GH, ed. Klassen und Ordnungen des Tierreichs. Fünfter

517 Band 5, 1 Abteilung, 7 Buch, 12 Lieferung. pp. 1505-1672.

518 Becker c, Türkay M, Brandis D. 2012. The male copulatory system of European pea crabs

519 (Crustacea, Brachyura, Pinnotheridae). Journal of Morphology 273(11): 1199-1318

$520 \quad$ https://doi.org/10.1002/jmor.20065 
521 Becker C, Türkay M. 2017. Host specificity and feeding in European pea crabs (Brachyura,

522 Pinnotheridae). Crustaceana 90(7-10):819-844 https://doi.org/10.1163/15685403-

$523 \underline{00003661}$

524 Brandão M, Freire AS, Burton RS. 2016. Estimating diversity of crabs (Decapoda: Brachyura)

525 in a no-take marine protected area of the SW Atlantic coast through DNA barcoding of

526 larva. Systematics and Biodiversity 14(3):288-302

527

https://doi.org/10.1080/14772000.2016.1140245

528 Bousquette GD. 1980. The larval development of Pinnixa longipes (Lockington, 1877)

529 (Brachyura: Pinnotheridae) reared in the laboratory. Biological Bulletin 159:592-605

$530 \quad$ https://doi.org/10.2307/1540825

531 Bürger O. 1895. Ein Beitrag zur kenntniss der Pinnotherinen. Zoologische Jahrbücher,

532 Abtheilung für Systematik, Geographie und Biologie der Thiere 8:361-390.

533 Campos E, Díaz V, Gamboa-Contreras JA. 1998. Notes on distribution and taxonomy of five

534 poorly known species of pinnotherid crabs from the eastern Pacific (Crustacea: Brachyura:

535 Pinnotheridae). Proceedings of the Biological Society of Washington 111:372-381.

536 Campos E, Peláez-Zárate V, Solís-Marín FA. 2012. Rediscovery, host and systematics of

537 Holothuriophilus trapeziformis Nauck, 1880 (Crustacea, Brachyura, Pinnotheridae).

$538 \quad$ Zootaxa 3528:57-62 https://doi.org/10.11646/zootaxa.3528.1.4

539 Caso ME. 1958. Contribución al conocimiento de los holoturoideos de México. III. Algunas

540 especies de holoturoideos litorales de la costa Pacífica de México. Anales del Instituto de

541 Biología, Universidad Nacional Autónoma de México 28:309-338. 
542 Caso ME. 1964. Contribución al conocimiento de los holoturoideos de México. Descripción de

543 una n. sp. de Holothuria de un nuevo subgénero (Paraholothuria N. SG.). Anales del

544 Instituto de Biología, Universidad Nacional Autónoma de México 34(1-2):367-380.

545 Caso ME. 1965. Estudio sobre Equinodermos de México. Contribución al conocimiento de los 546 holoturoideos de Zihuatanejo y de la Isla de Ixtapa (primera parte). Anales del Instituto de 547 Biología, Universidad Nacional Autónoma de México 36:253-291.

548 Cassone JB, Boulding GE. 2006. Genetic structure and phylogeography of the lined shore crab, 549 Pachygrapsus crassipes, along the northeastern and western Pacific coast. Marine Biology $550 \quad$ 149:213-226 https://doi.org/10.1007/s00227-005-0197-9

551 Costa FO, De Waard JR, Boutillier J, Ratnasingham S, Dooh RT, Hajibabaei M, Hebert

552 PDN. 2007. Biological identification through DNA barcodes: the case of the Crustacea.

553 Canadian Journal of Fisheries and Aquatic Science 64:272-295

$554 \quad$ https://doi.org/10.1139/f07-008

555 Darriba D, Taboada GL, Doallo R, Posada D. 2011. jModelTest 2: more models, new

556 heuristics and parallel computing. Nature Methods 9(8):772

$557 \quad$ https://doi.org/10.1038/nmeth.2109

558 Derby CD, Antema J. 1980. Induced host odor attraction in the pea crab Pinnotheres maculatus. Biological Bulletin 158:26-33 https://doi.org/10.2307/1540755

De Man JG. 1887. Uebersicht der Indo-pacifischen Arten der Gattung Sesarma Say, nebst einer Kritik der von W. Hess und E. Nauck in den Jahren 1865 und 1880 beschriebenen Decapoden. Zoologische Jahrbücher. Abteilung für Systematik, Geographie und Biologie der Tier 2:639-722. 
564 Elías-Gutiérrez M, Valdez-Moreno M, Topan J, Young MR, Cohulo-Colli JA. 2018.

565 Improved protocols to accelerate the assembly of DNA barcode reference libraries for

566 freshwater zooplankton. Ecology and Evolution 8:3002-3018

567 https://doi.org/10.1002/ece3.3742

568 Garth SJ. 1957. Reports of the Lund University Chile Expedition 1948-49, 29, The crustacea decapoda brachyura of Chile. Lunds Universitets Arsskrift. N.F. Avd. 2. Bd. 53. Nr. 7:1570 134.

571

572

Garm A, Watling L. 2013. The crustacean integument: setae, setules, and other ornamentation. In: Watling, L. \& Thiel, M. (Eds.) Functional morphology and diversity. The natural history of crustacean series, 1. Oxford University Press, Oxford, pp:167-198 https://doi.org/10.1093/acprof:osobl/9780195398038.003.0006

Gómez-Valdivia F, Parés-Sierra A, Flores-Morales AL. 2015. The Mexican Coastal Current: A subsurface seasonal bridge that connects the tropical and subtropical Northeastern Pacific. Continental Shelf Research 110:100-107 https://doi.org/10.1016/j.csr.2015.10.010

Guilherme PDB, Brustolin MC, de Bueno ML. 2015. Distribution of ectosimbiont crabs and their sand dollar host in a subtropical estuarine sandflat. International Journal of Tropical Biology, Revista de Biología Tropical 63(2):209-220.

Haines CMC, Edmunds M, Pewsey AR. 1994. The pea crab, Pinnotheres pisum (Linnaeus 1767), and its association with the common mussel, Mytilus edulis (Linnaeus, 1758), in the Solent (U.K.). Journal of Shellfish Research 13:5-10.

Hajibabaei M, Singer GAC, Hebert PDN, Hickey DA. 2007. DNA barcoding: how it complements taxonomy, molecular phylogenetics and population genetics. TRENDS in Genetics 23(4):167-172 https://doi.org/10.1016/j.tig.2007.02.001 
587 Hajibabaei M, De Waard JR, Ivanova NV, Ratnasingham S, Dooh RT, Kirk SL, Mackie

588 PM, Hebert PDN. 2005. Critical factors for assembling a high volume of DNA barcodes.

589 Philosophical Transactions of The Royal Society of London B Biological Science

$590 \quad 360: 1959-1967$ https://doi.org/10.1098/rstb.2005.1727

591 Hall TA. 1999. BioEdit: a user-friendly biological sequence alignment editor and analysis program for Windows 95/98/NT. Nucleic Acids Symposium Series 41:95-98.

593 Hamel JF, Ng PKL, Mercier A. 1999. Life cycle of the pea crab Pinnotheres halingi sp. nov., and obligate symbiont of the sea cucumber Holothuria scabra Jaeger. Ophelia 50(3):149175 https://doi.org/10.1080/00785326.1999.10409393

Hebert PND, Cywinska A, Ball SL, De Waard JR. 2003. Biological identification through DNA Barcodes. Proceedings of the Royal Society of London. Series B, Biological Science 270 (1512):313-321 https://doi.org/10.1098/rspb.2002.2218

Honey-Escandón M, Solís-Marín FA. 2018. A revision of Holoturia (Halodeima) kefersteinii (Selenka, 1867) and the revival of Holothuria inornata Semper, 1868 from sea cucumbers collected in Mexico and Central America. Zootaxa 4377(2):151-77 https://doi.org/10.11646/zootaxa.4377.2.1

Hurtado LA, Mateos M, Santamaria CA. 2010. Phylogeography of supralitoral rocky intertidal Ligia isopods in the Pacific region from Central California to Central Mexico.

Hurtado LA, Frey M, Guebe P, Pfeiler E, Markow TA. 2007. Geographical subdivision, PLoS ONE 5(7):e11633 https://doi.org/10.1371/journal.pone.0011633 demographic history and gene flow in two sympatric species of intertidal snails, Nerita scabricosta and Nerita funiculate, from the tropical eastern Pacific. Marine Biology 151:1863-1873 https://doi.org/10.1007/s00227-007-0620-5 
610 Ivanova NV, De Waard JR, Hebert, PDN. 2006. An inexpensive, automation-friendly protocol

611 for recovering high-quality DNA. Molecular Ecology Notes 6:998-1002

$612 \quad$ https://doi.org/10.1111/j.1471-8286.2006.01428.x

613 Laurenzano C, Mantelatto FL, Schubart CD. 2013. South American homogeneity versus

614 Caribbean heterogeneity: populations genetic structure of the western Atlantic fiddler crab

615 Uca rapax (Brachyura, Ocypodidae). Journal of Experimental Marine Biology and

616 Ecology 449:22-27 https://doi.org/10.1016/j.jembe.2013.08.007

617 Lefébure T, Douady CJ, Gouy M, Gibert J. 2006. Relationship between morphological and

618 molecular divergence within Crustacea: Proposal of a molecular threshold to help species

619 delimitation. Molecular Phylogenetics and Evolution 40(2006):435-447

$620 \quad \underline{\text { https://doi.org/10.1016/j.ympev.2006.03.014 }}$

621 Manning RB. 1993. Three genera remove from the synonymy of Pinnotheres Bosc, 1802

622 (Brachyura: Pinnotheridae). Proceedings of the Biological Society of Washington 106(3):

$623 \quad 523-531$.

624 Mantelatto FL, Carvalho FL, Simões SM, Negri M, Souza-Carvalho EA, Terossi M. 2016.

625 New primers for amplification of cytochrome c oxidase subunit I barcode region designes

626 for species of Decapoda (Crustacea). Nauplius 24: e2016030

627 https://doi.org/10.1590/2358-2936e2016030

628 Matzen da Silva J, Creer S, dos Santos A, Costa AC, Cunha MR, Costa FO, Carvalho GR.

629 2011. Systematic and evolutionary insights derived from mtDNA COI barcode Diversity in

630 the Decapoda (Crustacea: Malacostraca). PloS ONE 6(5):1-15, e19449

$631 \quad$ https://doi.org/10.1371/journal.pone.0019449

632 Nauck E. 1880. Das Kaugerüst der Brachyuren. Zeitschrift für wissenschaftliche Zoologie

$633 \quad$ (Leipzig) 34:1-69. 
634 Nei M, Kumar S. 2000. Molecular Evolution and Phylogenetics. Oxford University Press, New $635 \quad$ York

636 Ng PKL, Manning RB. 2003. On two new genera of pea crabs parasitic in holothurians

637 (Crustacea: Decapoda: Brachyura: Pinnotheridae) from the Indo-West Pacific, with notes 638 on allied genera. Proceedings of the Biological Society of Washington 116:901-919.

639 Nobili G. 1901. Decapodi raccolri dal Dr. Filippo Silvestri nell' America meridionale. Bollettino 640 del Musei di Zoologia ed Anatomia comparata della R. Univerith di Torino 16(402):1-16.

641 Ocampo EH, Nuñez JD, Lizarralde MS, Cledón M. 2011. Larval development of 642 Calyptraeotheres garthi (Fenucci, 1975) (Brachyura, Pinnotheridae) described from 643 Helgoland Marine Research 65:347-359 https://doi.org/10.1007/s10152-010-0228-x

645 Ocampo EH, Nuñez JD, Cledón M, Baeza JA. 2012. Host-specific reproductive benefits, host selection behaviour and host use pattern of the pinnotherid crab Calyptraeotheres granthi. Journal of Experimental Marine Biology and Ecology 429: 36-46 https://doi.org/10.1016/j.jembe.2012.06.009

Ocampo EH, Robles R, Terossi M, Nuñez JD, Cledón M, Mantelato FL. 2013. Phylogeny, phylogeography, and systematics of the American pea crab genus Calyptraeotheres, Campos, 1990, inferred from molecular markers. Zoological Journal of the Linnean Society 169:27-42 https://doi.org/10.1111/zoj.12045

Palacios-Theil E, Cuesta JA, Felder DL. 2016. Molecular evidence for non-monophyly of the pinnotheroid crabs (Crustacea: Brachyura: Pinnotheroidea), warranting taxonomic reappraisal. Invertebrate Systematics 30:1-27 https://doi.org/10.1071/IS15023 
656 Paz-García DA, Chávez-Romo HE, Correa-Sandoval F, Reyes-Bonilla H, López-Pérez A, 657 Medina-Rosas P, Hernández-Cortés MP. 2012. Genetic connectivity patterns of corals 658 Pocillopora damicornis and Porites panamensis (Anthozoa: Scleractinia) along the West 659 Coast of Mexico. Pacific Science 66(1): 43-61 https://doi.org/10.2984/66.1.3

660

661

662

663

664

665

666

667

668

669

670

671

672

673

674

675

676

677

\section{Perez-Miguel M, Drake P, García-Raso EJ, Mamán-Menéndez J, Navas IJ, Cuesta AJ.} 2019. European Pinnotheridae (Crustacea, Decapoda, Brachyura): species, distribution, host use and DNA barcode. Marine Biodiversity 49:57-68 https://doi.org/10.1007/s12526-

Poeppig E. 1836. Crustacea Chilensia nova aut minus nota descripsit. Archiv Für Naturgeschichte 2(1):133-145.

Posada D, Buckley TR. 2004. Model selection and model averaging in phylogenetics: advantages of Akaike information criterion and Bayesian approaches over Likelihood Ratio Test. Systematic Biology 53(5):739-808 https://doi.org/10.1080/10635150490522304

Prieto-Rios, E, Solís-Marín FA, Borrero-Pérez GH, Díaz-Jaimes P. 2014. Filogeografía de Holothuria (Halodeima) inornata Semper, 1868 (Echinodermata: Holothuroidea). Revista Peruana de Biología 21(2):155-162 https://doi.org/10.15381/rpb.v21i2.9818

Prosser S, Martínez-Arce A, Elías-Gutiérrez M. 2013. A new set of primers for COI amplification from freshwater microcrustaceans. Molecular Ecology Resources 13:11511155 https://doi.org/10.1111/1755-0998.12132

Rathbun MJ. 1918. The grapsoid crabs of America. Bulletin of the United States National Museum 97:1-461 https://doi.org/10.5479/si.03629236.97.i 
678 Ratnasingham S, Hebert PDN. 2013. A DNA-based registry for all animal species: The

679 Barcode Index Number (BIN) system. PLoS ONE 8(7):e66213

680 https://doi.org/10.1371/journal.pone.0066213

681 Rossi N, Mantelatto FL. 2013. Molecular analysis of the freshwater prawn Macrobrachium 682 olfersii (Decapoda, Palaemonidae) supports the existence of a single species throughout its distribution. PLoS ONE 8(1):e54698 https://doi.org/10.1371/journal.pone.0054698

Salgado-Barragán J. 2015. A new species of Pinnixa (Crustacea: Brachyura: Pinnotheridae) from Mazatlan, Sinaloa, Mexico. Revista Mexicana de Biodiversidad 86(3):629-636 http://dx.doi.org/10.1016/j.rmb.2015.03.001

Santos-Beltrán C, Salazar-Silva P. 2011. Holothuroideos (Echinodermata: holoturoidea) de playas rocosas, zona norte de Bahía Banderas, Nayarit, México. Ciencia y Mar 15(45):3-

689 11.

Schmitt WL, McCain JC, Davidson ES. 1973. Fam. Pinnotheridae, Brachyura I: Decapoda I. In: Gruner HE, Holthuis LB, eds. Crustaceorum Catalogus 3:1-160.

Semper, C. 1867-1868. Holothurien. In: Semper, C., ed. Reisen im Archipel der Philippinen. Zweiter Theil. Wissenschaftliche Resultate. Erster Band. Leipzig: W. Engelmann. iv + 288 pp., 40 pls.

Solís-Marín FA, Arriaga-Ochoa JA, Laguarda-Figueras A, Frontana-Uribe SC, DuránGonzález A. 2009. Holoturoideos (Echinodermata: Holothuroidea) del Golfo de California. CONABIO-UNAM-ICMyL, México, 177 pp. marker regions for identification of food relevant crustaceans of the order Decapoda. 
Tamura K, Stecher G, Peterson D, Filipski A, Kumar S. 2013. MEGA6: Molecular

703

704

705

706

707

708

709

710

711

712

713

714

715

716

717

718

719

720

721 Evolutionary Genetics Analysis version 6.0. Molecular Biology and Evolution 30:27252729 https://doi.org/10.1093/molbev/mst197

Wares JP, Gaines SD, Cunningham, CW. 2001. A comparative study of asymmetric migration events across a marine biogeographic boundary. Evolution 55:295-306 https://doi.org/10.1111/j.0014-3820.2001.tb01294.x

Will WK, Rubinoff D. 2004. Myth of the molecule: DNA barcodes for species cannot replace morphology for identification and classification. Cladistics 20:47-55 https://doi.org/10.1111/j.1096-0031.2003.00008.x

Zhang C, Li Q, Wu X, Liu Q, Cheng Y. 2017. Genetic diversity and genetic structure of farmed and wild Chinese mitten crab (Eriocheir sinensis) populations from three major basins by mitochondrial DNA COI and Cyt b gene sequences. Mitochondrial DNA PART A 2-9 https://doi.org/10.1080/24701394.2017.1404048

Zhou H, Xu J, Yang M, Wu B, Yan B, Xiong Y. 2015. Population genetic diversity of sesarmid crab (Perisesarma bidens) in China based on mitochondrial DNA. Mitochondrial DNA, Early Online 1-8 https://doi.org/10.3109/19401736.2015.1015002

\section{List of figures}

Figure 1. Sampling sites. A) northern region; type locality Mazatlan (fide Nauck, 1880); B-C) southern region. 
722 Figure 2. Holothuriophilus trapeziformis Nauck, 1880. A-C, male from Panteón Beach,

723 Oaxaca, Mexico (UMAR-DECA-308): A, dorsal view; B, ventral view; C, frontal view. D-F,

724 female from Agua Blanca Beach, Oaxaca, Mexico (UMAR-DECA-307): D, dorsal view; E,

725 ventral view; F, frontal view. G, male inside the gut of Holothuria (Halodeima) inornata, from

726 Pinitos Beach, Sinaloa, Mexico.

727 Figure 3. Holothuriophilus trapeziformis Nauck, 1880. A-D, male from Panteón Beach,

728 Oaxaca, Mexico (UMAR-DECA-308): A, dorsal view (bold arrow indicates the internal blunt

729 projection of the hepatic notch); B, frontal view (bold arrow indicates the hepatic notch); C,

730 third-fourth sternal plate (bold arrow indicates the crenulated margin of the third plate, white

731 arrow indicates the crenulated margin of the fourth plate); D, abdomen; E, abdominal view of the

732 left first gonopod; F, ventral view of the left second gonopod (bold arrow indicates the distal

733 notch); A, C, hollow circles indicating pits. Fine dots indicating pilosity. A-D, half of the

734 illustration without ornamentation.

735 Figure 4. Holothuriophilus trapeziformis Nauck, 1880. A, antenna. B, antennule: a, superior

736 palp; b, inferior palp; C, second maxilliped: a, endopod; b, exopod; c, exopod flagellum (bold

737 arrow indicates the subrounded dactylus); D, third maxilliped (setae not illustrated): a,

738 ischiomerus (white arrow indicates the conspicuous projection); b, carpus; c, propodus; $d$,

739 dactylus (bold arrow indicates the distal widened dactylus). E, exopod of the third maxilliped. F,

740 chela (upper bold arrow indicating mid-posterior teeth and the lower one the granulated inferior

741 margin; dashed bold arrow indicating the lamella; white arrow indicates the subdistal projection).

742 Figure 5. Comparison between males of Holothuriophilus trapeziformis Nauck, 1880 from

743 the Pacific coast of Mexico. A-D, Sinaloa (DECA-1190; CW= $8 \mathrm{~mm}$ ); E-H, Guerrero (DECA-

744 1148; CW= $8 \mathrm{~mm}$ ); I-L, Oaxaca (DECA-1270; CW= $8 \mathrm{~mm}$ ). A, E, I, carapace outline (white 
745 arrow indicates the hepatic notch, bold arrow indicates the lateral lobes); B, F, J, right chela,

746 external view (bold arrow indicates the proximal teeth, white arrow indicates the medial tooth,

747 dashed white arrow indicates the distal projection; dashed bold arrow indicates the medial tooth);

$748 \mathrm{C}, \mathrm{G}, \mathrm{K}$, left Mxp3 endopod, external view (bold arrow indicates the ischiomerus projection); D,

749 H, L, first gonopod in ventral view; e, gonopod tip in ventral view; f, gonopod tip, dorsal view

750 (e-f, white arrow indicates the truncated or acute distal margin and bold arrow indicates the

751 ventral process).

752 Figure 6. Comparison between ovigerous females of Holothuriophilus trapeziformis Nauck,

7531880 from the Pacific coast of Mexico. A-C, Sinaloa (UMAR-DECA-1192; CW= $8 \mathrm{~mm}$ ); D-F,

754 Guerrero (DECA-1149; CW= 8 mm); G-I, Oaxaca (UMAR-DECA-1182; CW= 8 mm); J, K,

755 chelae, external view, Oaxaca (UMAR-DECA-1172; CW=9 mm). A, D, G, carapace outline

756 (white arrow indicates the frontal notch, bold arrow indicates the hepatic notch); B, E, H, right

757 chela, external view (bold arrow indicates the proximal teeth, white arrow indicates the medial

758 tooth, dashed white arrow indicates the distal projection; dashed bold arrow indicates the medial

759 tooth); C, F, I, left Mxp3 endopod, external view (bold arrow indicates the ichiomerus

760 projection).

761 Figure 7. Comparison between females: Holothuriophilus trapeziformis Nauck, 1880 and $\boldsymbol{H}$.

762 pacificus (Poeppig, 1836). A-D, H. trapeziformis from Camarón Beach, Oaxaca, Mexico

763 (UMAR-DECA-1163): A, carapace; B, third maxilliped (bold arrow indicates the ischiomerus

764 projection); C, chela (dashed bold arrow indicates the inferior granulated margin); D, ovigerous

765 abdomen. E-H, H. pacificus from San Vicente, Chile (drawing after Garth 1957: figs. 10E, F, G,

$766 \mathrm{H}$ as Pinnaxodes silvestrii): E, carapace; F, third maxilliped; G, chela; H, abdomen. I-J, lectotype

767 of H. trapeziformis from Mazatlan, Mexico (drawing after Ahyong \& Ng 2007: Fig. 20 A, C) I, 
768 dorsal view of carapace; J, third maxilliped. K, H. trapeziformis from Guerrero, third maxilliped

769 of the adult female of (drawing after Campos, Peláez-Zárate, Solís-Marín 2012: Figs. 2B, C).

770 Scale of $\mathrm{E}=\mathrm{x} 3.5, \mathrm{~F}=\mathrm{x} 18.6, \mathrm{G}=\mathrm{x} 4.6, \mathrm{H}=\mathrm{x} 2.9$ (fide Garth 1957).

771 Figure 8. Comparison between males: Holothuriophilus trapeziformis Nauck, 1880 and $\boldsymbol{H}$.

772 pacificus (Poeppig, 1836). A-C, from Panteón Beach, Oaxaca, Mexico; C, ventral view of the

773 first gonopod, Mexico (UMAR-DECA-308). D-F, from Talcahuano, Chile (drawing after Garth

774 1957: Figs. 11A, B, C). A, D, third maxilliped; a, dactylus; b, propodus; c, exopod flagellum. B,

775 F, abdomen. C, F, first gonopod. Scale of $\mathrm{D}=\mathrm{x} 21, \mathrm{E}=\mathrm{x} 6, \mathrm{~F}=\mathrm{x} 25$ (fide Garth 1957).

776 Figure 9. Condensed unrooted Maximum likelihood tree based on mitochondrial

777 cytochrome c oxidase (COI) with the General Time Reversible with gamma distribution

778 (GTR+G) model. Data: BOLD process ID, species name, associated BIN. Branch values

779 represent bootstrap probabilities (1000 permutations). 
Figure 1

\section{Sampling sites}

A) northern region; type locality Mazatlan (fide Nauck, 1880); B-C) southern region.
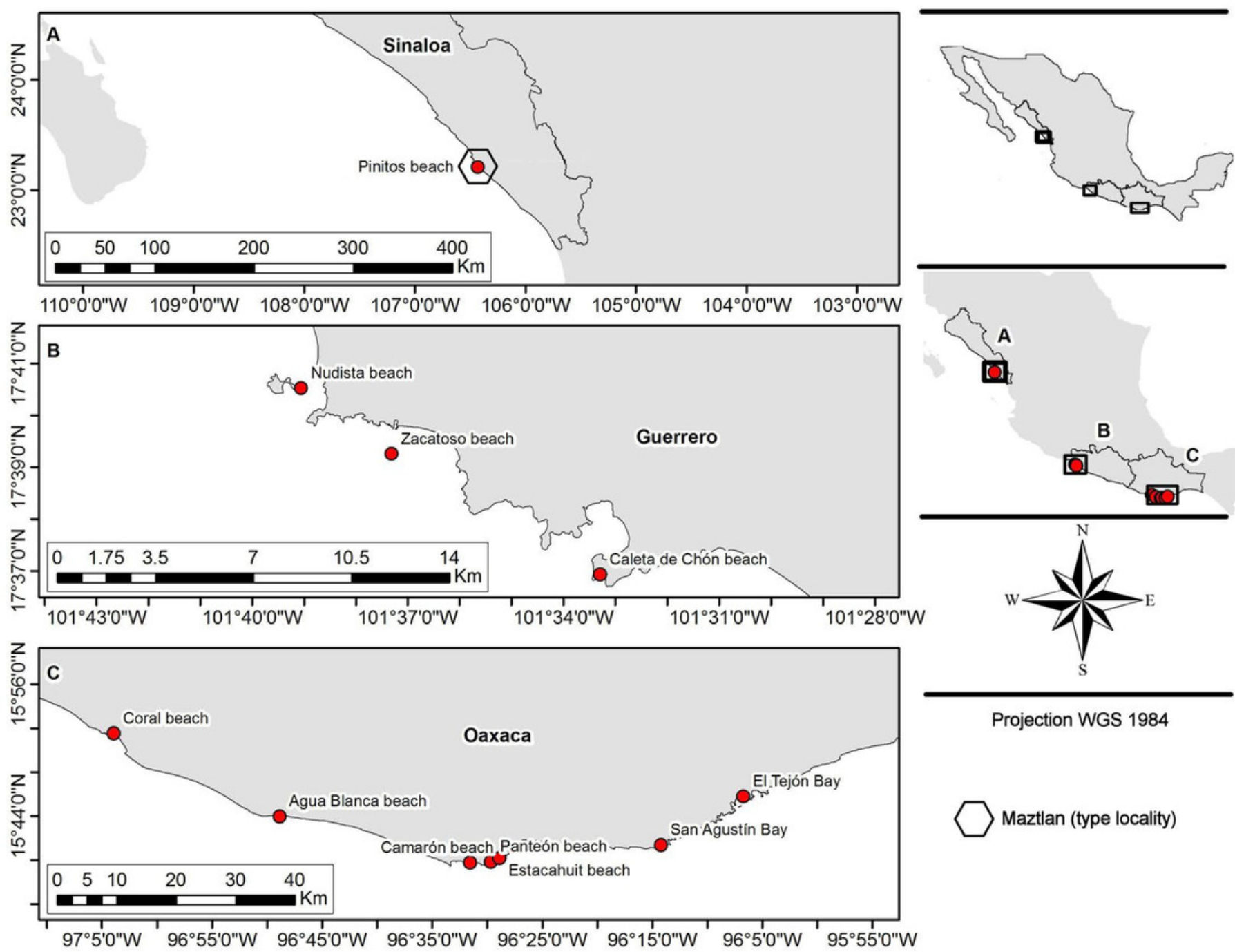

Projection WGS 1984

$\square$ Maztlan (type locality) 
Figure 2

Holothuriophilus trapeziformis Nauck, 1880

A-C, male from Panteón Beach, Oaxaca, Mexico (UMAR-DECA-308): A, dorsal view; B, ventral view; C, frontal view. D-F, female from Agua Blanca Beach, Oaxaca, Mexico (UMARDECA-307): D, dorsal view; $E$, ventral view; $F$, frontal view. $G$, male inside the gut of Holothuria (Halodeima) inornata, from Pinitos Beach, Sinaloa, Mexico. 


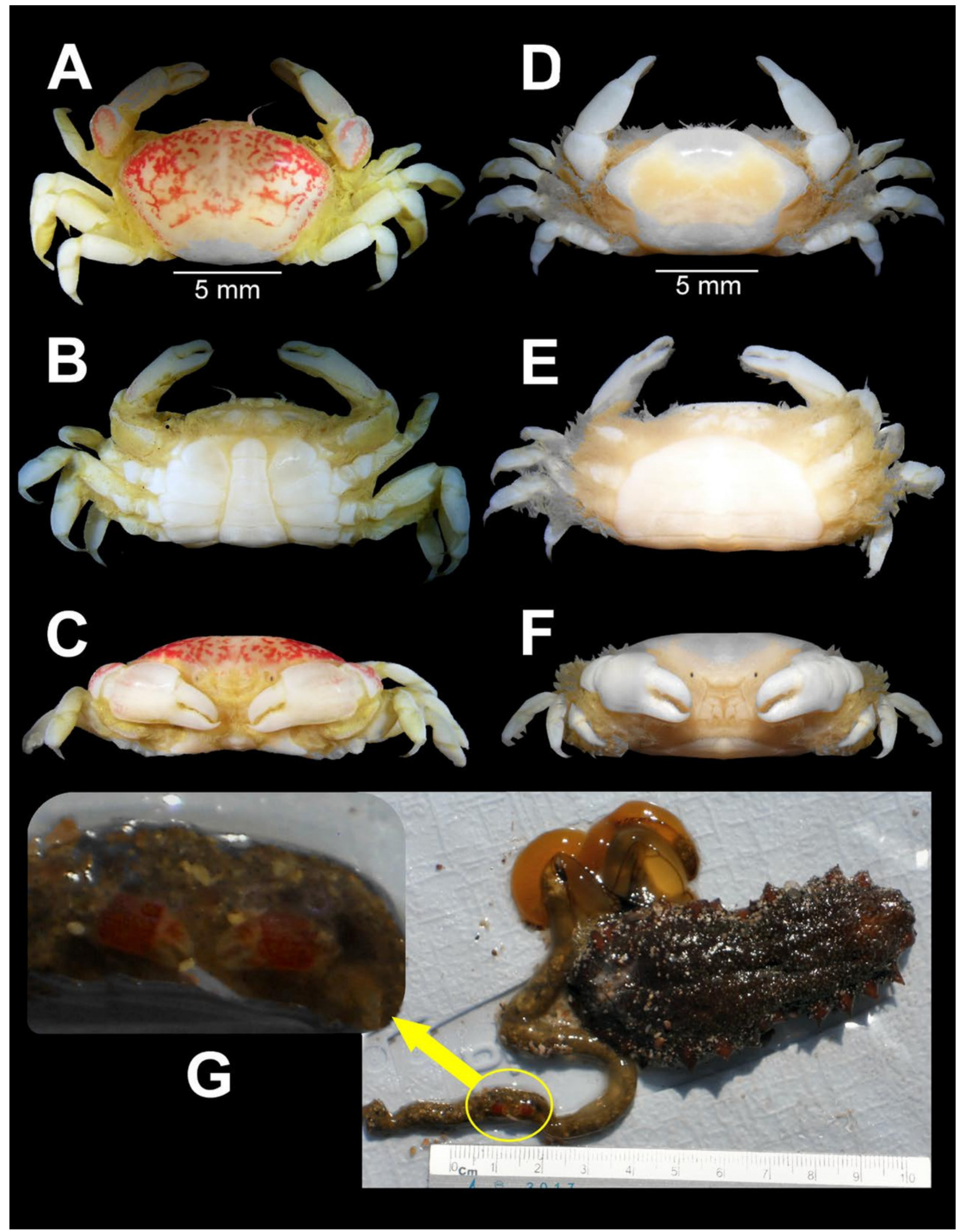




\section{Figure 3}

Holothuriophilus trapeziformis Nauck, 1880

A-D, male from Panteón Beach, Oaxaca, Mexico (UMAR-DECA-308): A, dorsal view (bold arrow indicates the internal blunt projection of the hepatic notch); $B$, frontal view (bold arrow indicates the hepatic notch); C, third-fourth sternal plate (bold arrow indicates the crenulated margin of the third plate, white arrow indicates the crenulated margin of the fourth plate); $D$, abdomen; $E$, abdominal view of the left first gonopod; $F$, ventral view of the left second gonopod (bold arrow indicates the distal notch); A, C, hollow circles indicating pits. Fine dots indicating pilosity. A-D, half of the illustration without ornamentation. 


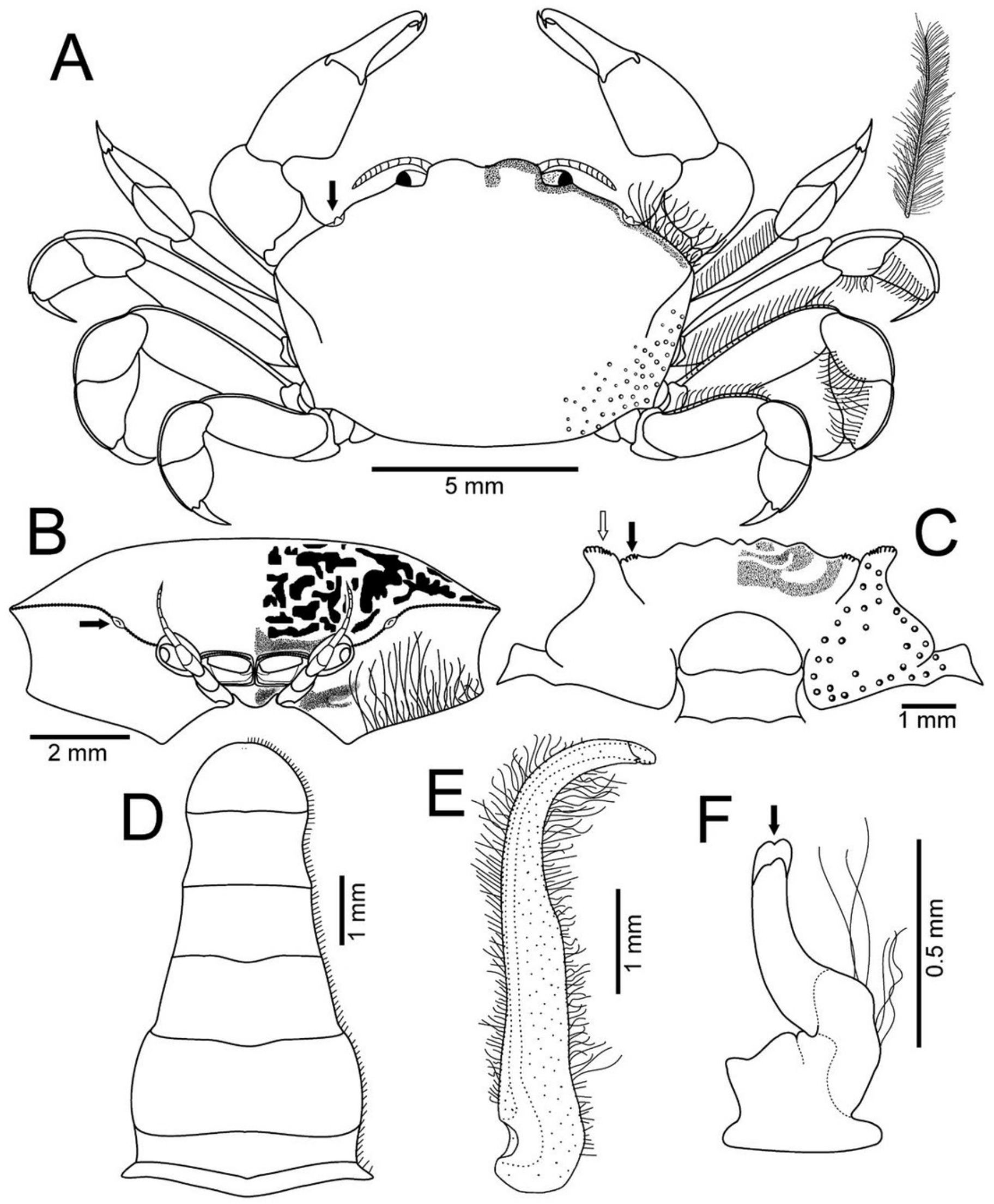




\section{Figure 4}

Holothuriophilus trapeziformis Nauck, 1880

A, antenna. B, antennule: a, superior palp; b, inferior palp; C, second maxilliped: a, endopod;

b, exopod; c, exopod flagellum (bold arrow indicates the subrounded dactylus); D, third maxilliped (setae not illustrated): a, ischiomerus (white arrow indicates the conspicuous projection); b, carpus; c, propodus; d, dactylus (bold arrow indicates the distal widened dactylus). E, exopod of the third maxilliped. F, chela (upper bold arrow indicating midposterior teeth and the lower one the granulated inferior margin; dashed bold arrow indicating the lamella; white arrow indicates the subdistal projection). 


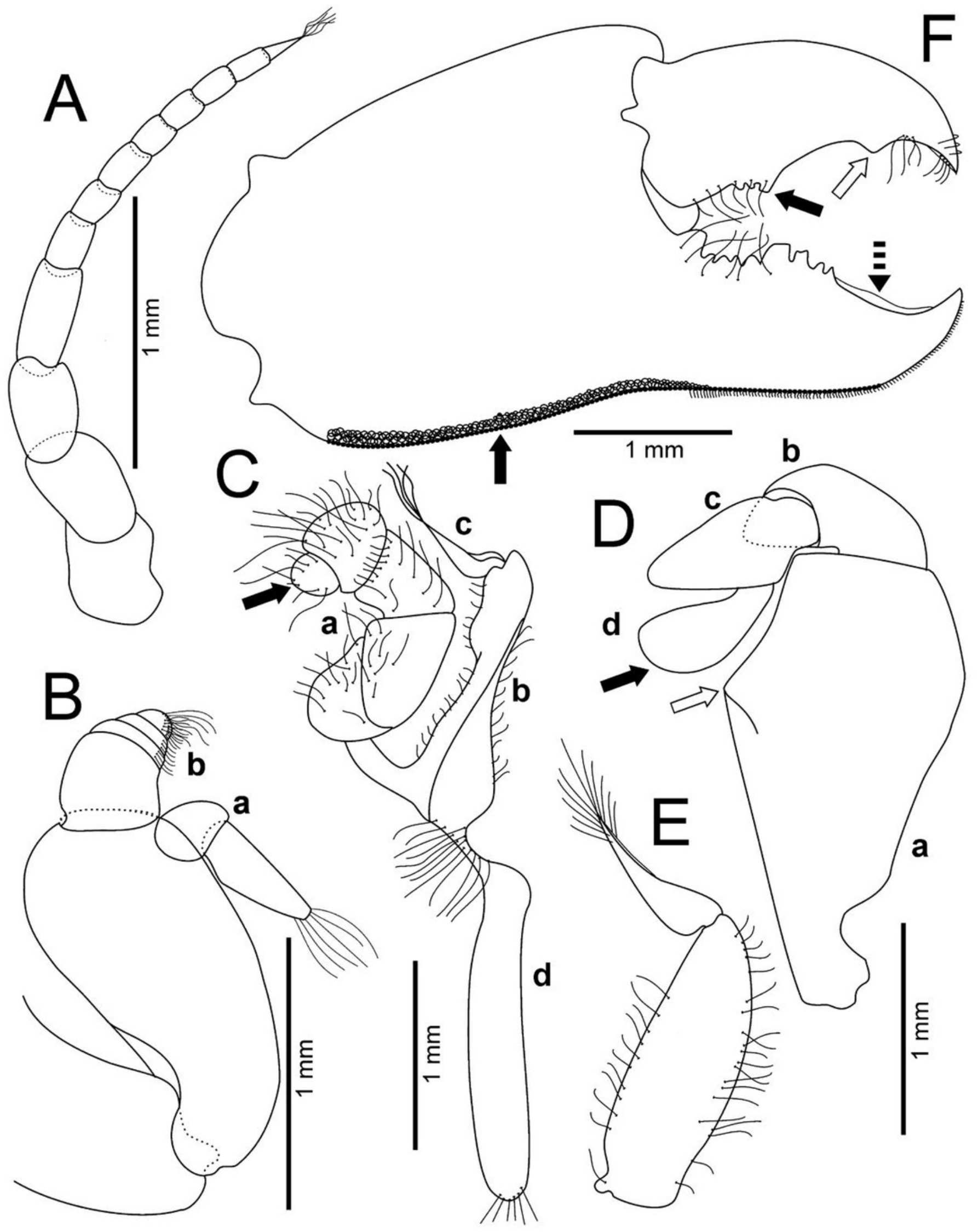

Peer) reviewing PDF | (2021:02:57986:4:0:NEW 8 Dec 2021) 


\section{Figure 5}

Comparison between males of Holothuriophilus trapeziformis Nauck, 1880 from the Pacific coast of Mexico

A-D, Sinaloa (DECA-1190; CW= $8 \mathrm{~mm}$ ); E-H, Guerrero (DECA-1148; CW= $8 \mathrm{~mm}$ ); I-L, Oaxaca (DECA-1270; CW $=8 \mathrm{~mm}$ ). A, E, I, carapace outline (white arrow indicates the hepatic notch, bold arrow indicates the lateral lobes); B, F, J, right chela, external view (bold arrow indicates the proximal teeth, white arrow indicates the medial tooth, dashed white arrow indicates the distal projection; dashed bold arrow indicates the medial tooth); C, G, K, left Mxp3 endopod, external view (bold arrow indicates the ischiomerus projection); D, H, L, first gonopod in ventral view; e, gonopod tip in ventral view; f, gonopod tip, dorsal view (e-f, white arrow indicates the truncated or acute distal margin and bold arrow indicates the ventral process). 


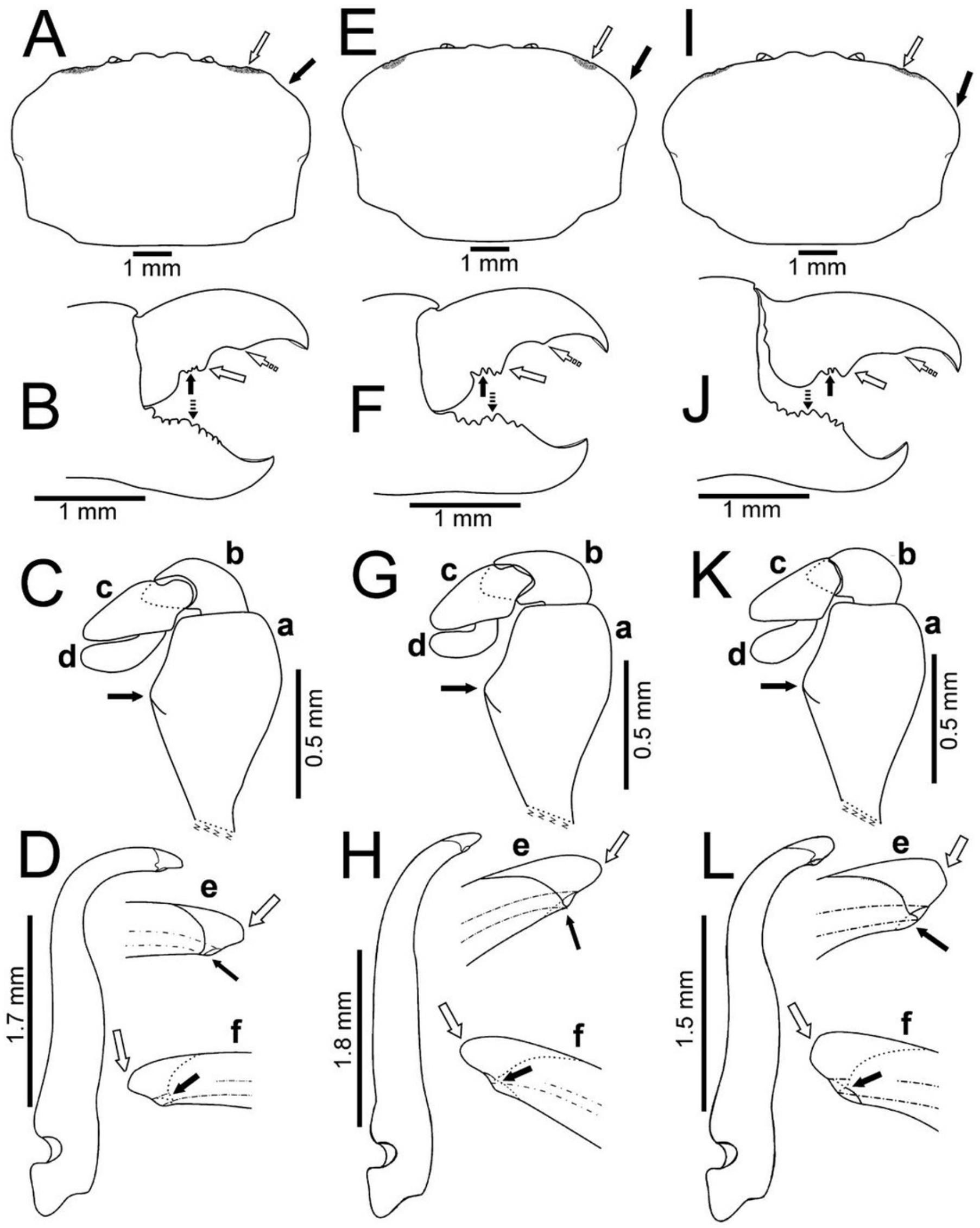




\section{Figure 6}

Comparison between ovigerous females of Holothuriophilus trapeziformis Nauck, 1880 from the Pacific coast of Mexico

A-C, Sinaloa (UMAR-DECA-1192; CW= $8 \mathrm{~mm}$ ); D-F, Guerrero (DECA-1149; CW= $8 \mathrm{~mm}$ ); G-I, Oaxaca (UMAR-DECA-1182; CW= $8 \mathrm{~mm}$ ); J, K, chelae, external view, Oaxaca (UMAR-

DECA-1172; CW= $9 \mathrm{~mm}$ ). A, D, G, carapace outline (white arrow indicates the frontal notch, bold arrow indicates the hepatic notch); B, E, H, right chela, external view (bold arrow indicates the proximal teeth, white arrow indicates the medial tooth, dashed white arrow indicates the distal projection; dashed bold arrow indicates the medial tooth); C, F, I, left Mxp3 endopod, external view (bold arrow indicates the ichiomerus projection). 

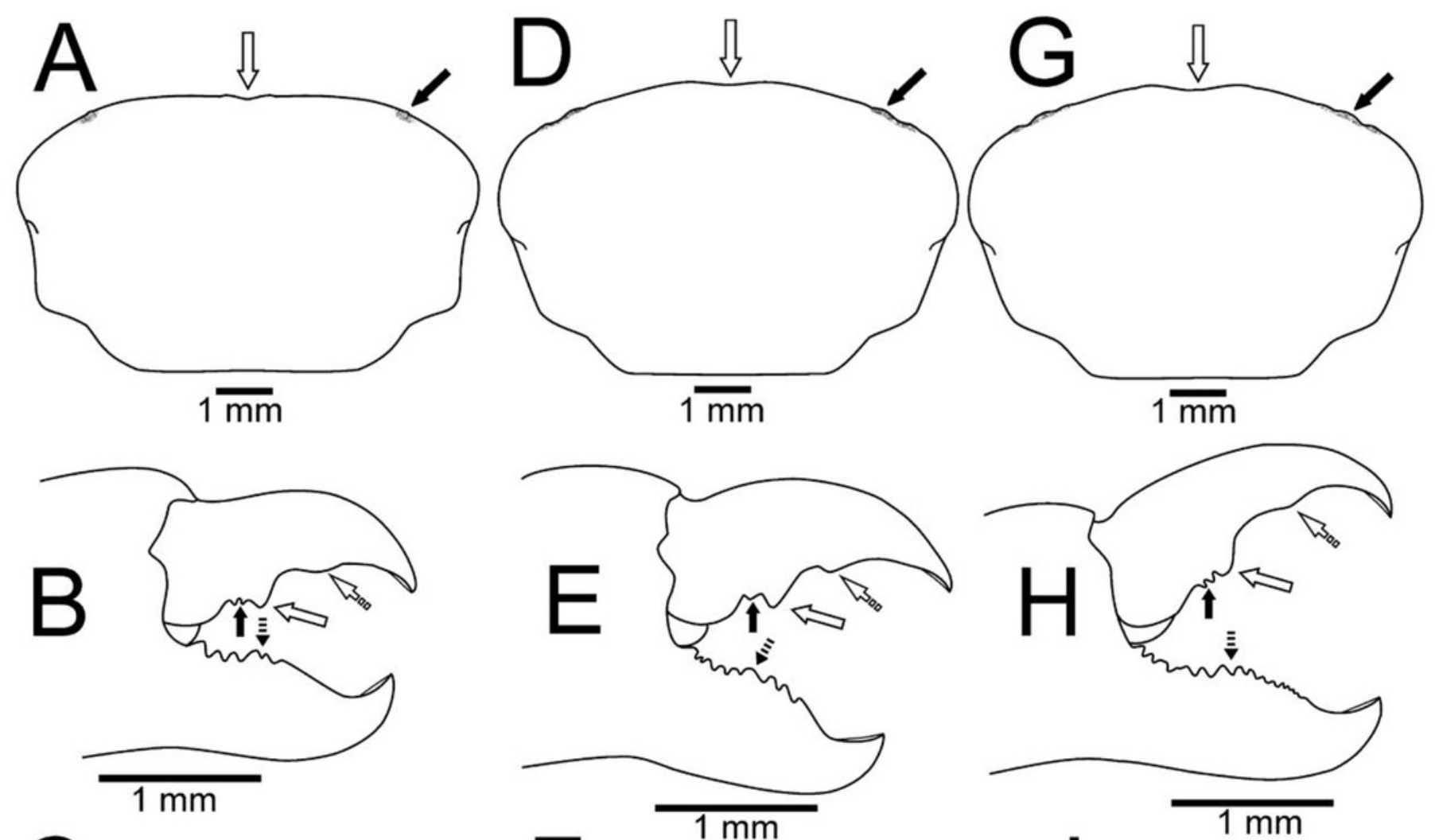

C

J
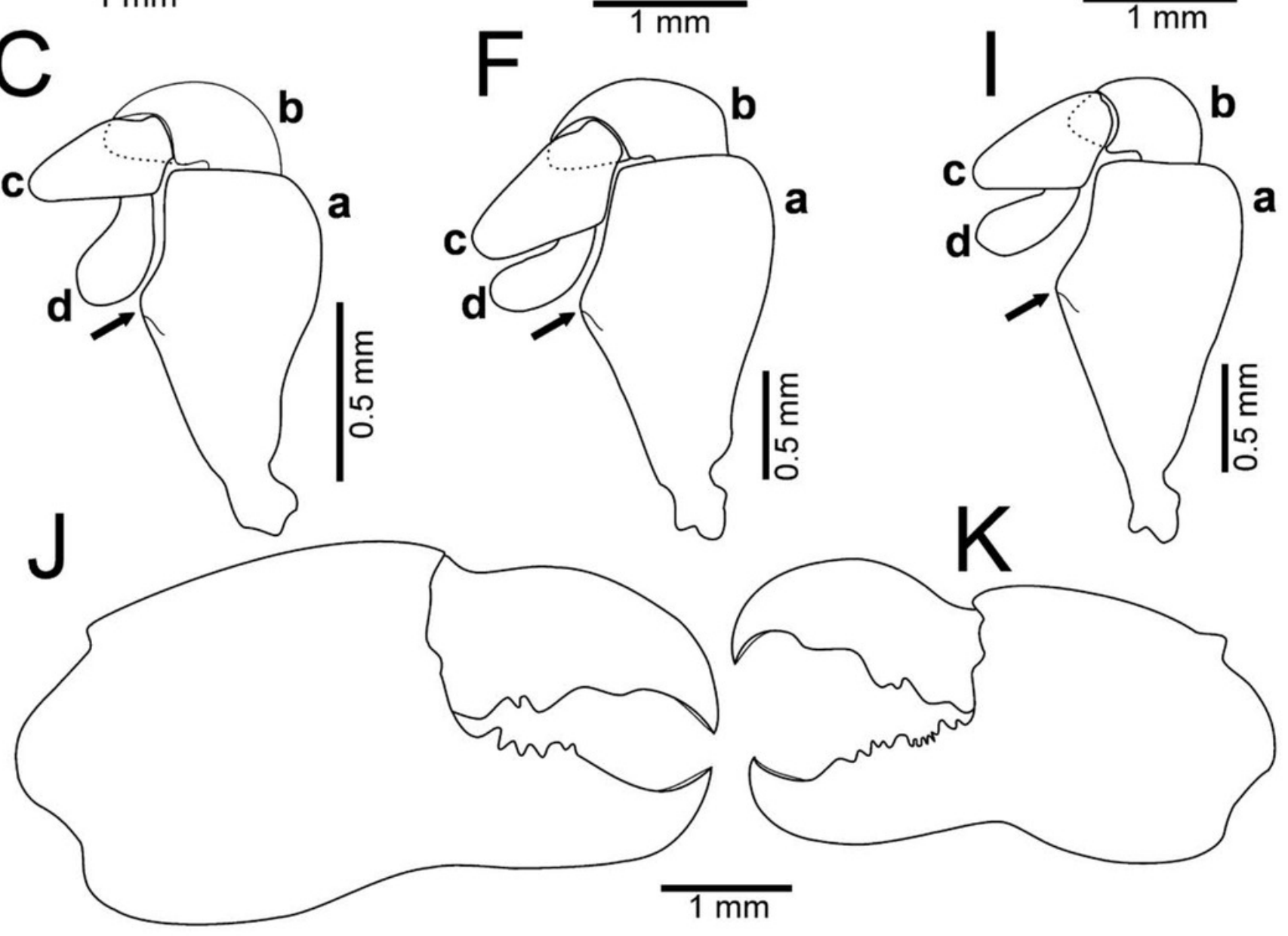


\section{Figure 7}

Comparison between females: Holothuriophilus trapeziformis Nauck, 1880 and $\mathrm{H}$. pacificus (Poeppig, 1836)

A-D, H. trapeziformis from Camarón Beach, Oaxaca, Mexico (UMAR-DECA-1163): A, carapace;

$B$, third maxilliped (bold arrow indicates the ischiomerus projection); $C$, chela (dashed bold arrow indicates the inferior granulated margin); D, ovigerous abdomen. E-H, H. pacificus from San Vicente, Chile (drawing after Garth 1957: figs. 10E, F, G, H as Pinnaxodes silvestrii): $\mathrm{E}$, carapace; F, third maxilliped; $\mathrm{G}$, chela; $\mathrm{H}$, abdomen. I-J, lectotype of $H$. trapeziformis from Mazatlan, Mexico (drawing after Ahyong \& Ng 2007: Fig. 20 A, C) I, dorsal view of carapace; J, third maxilliped. $K, H$. trapeziformis from Guerrero, third maxilliped of the adult female of (drawing after Campos, Peláez-Zárate, Solís-Marín 2012: Figs. 2B, C). Scale of E=x3.5, F= x18.6, $G=x 4.6, H=x 2.9$ (fide Garth 1957). 


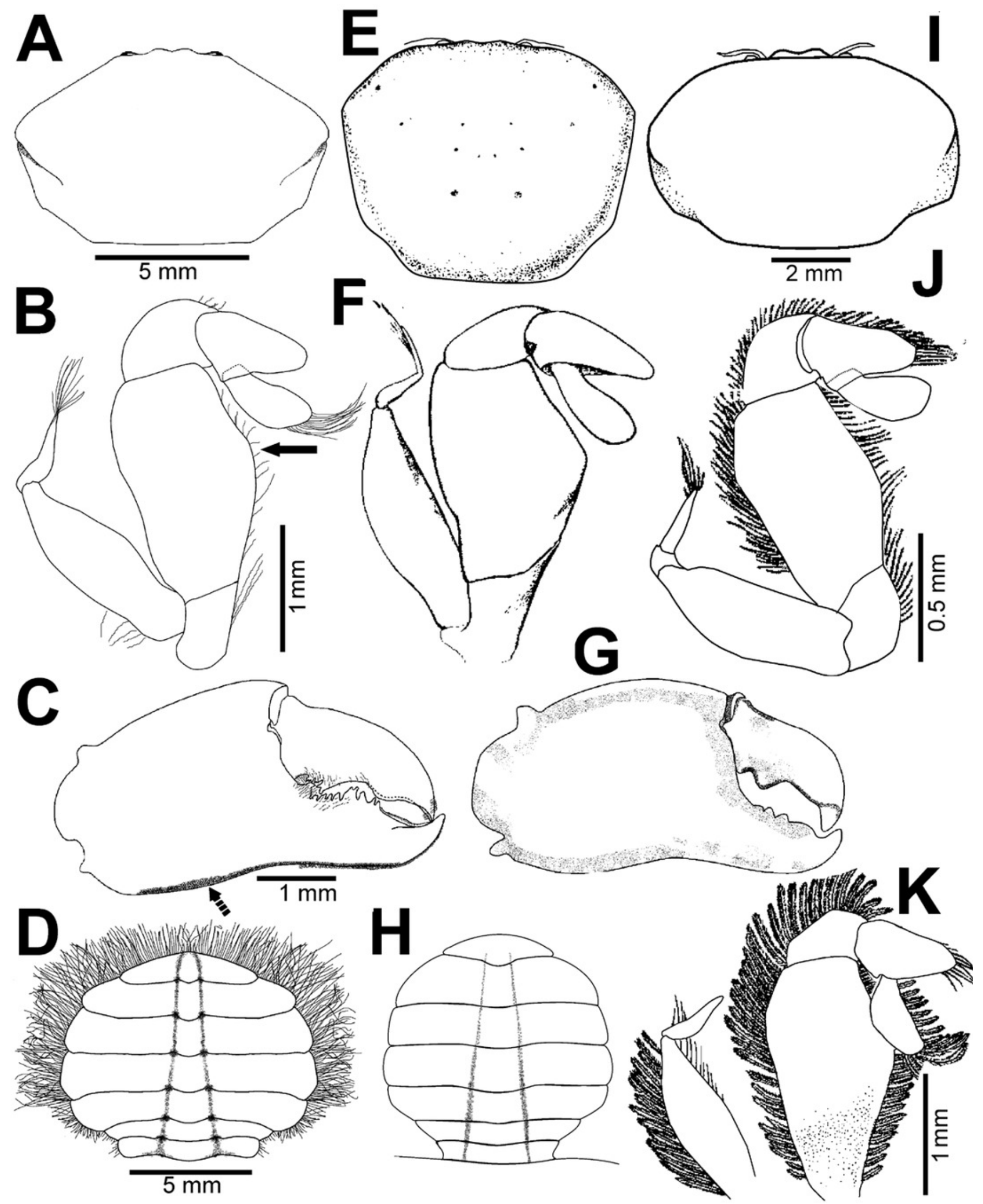




\section{Figure 8}

Comparison between males: Holothuriophilus trapeziformis Nauck, 1880 and $H$. pacificus (Poeppig, 1836)

A-C, from Panteón Beach, Oaxaca, Mexico; C, ventral view of the first gonopod, Mexico (UMAR-DECA-308). D-F, from Talcahuano, Chile (drawing after Garth 1957: Figs. 11A, B, C).

A, D, third maxilliped; a, dactylus; b, propodus; c, exopod flagellum. B, F, abdomen. C, F, first gonopod. Scale of $D=x 21, E=x 6, F=x 25$ (fide Garth 1957). 

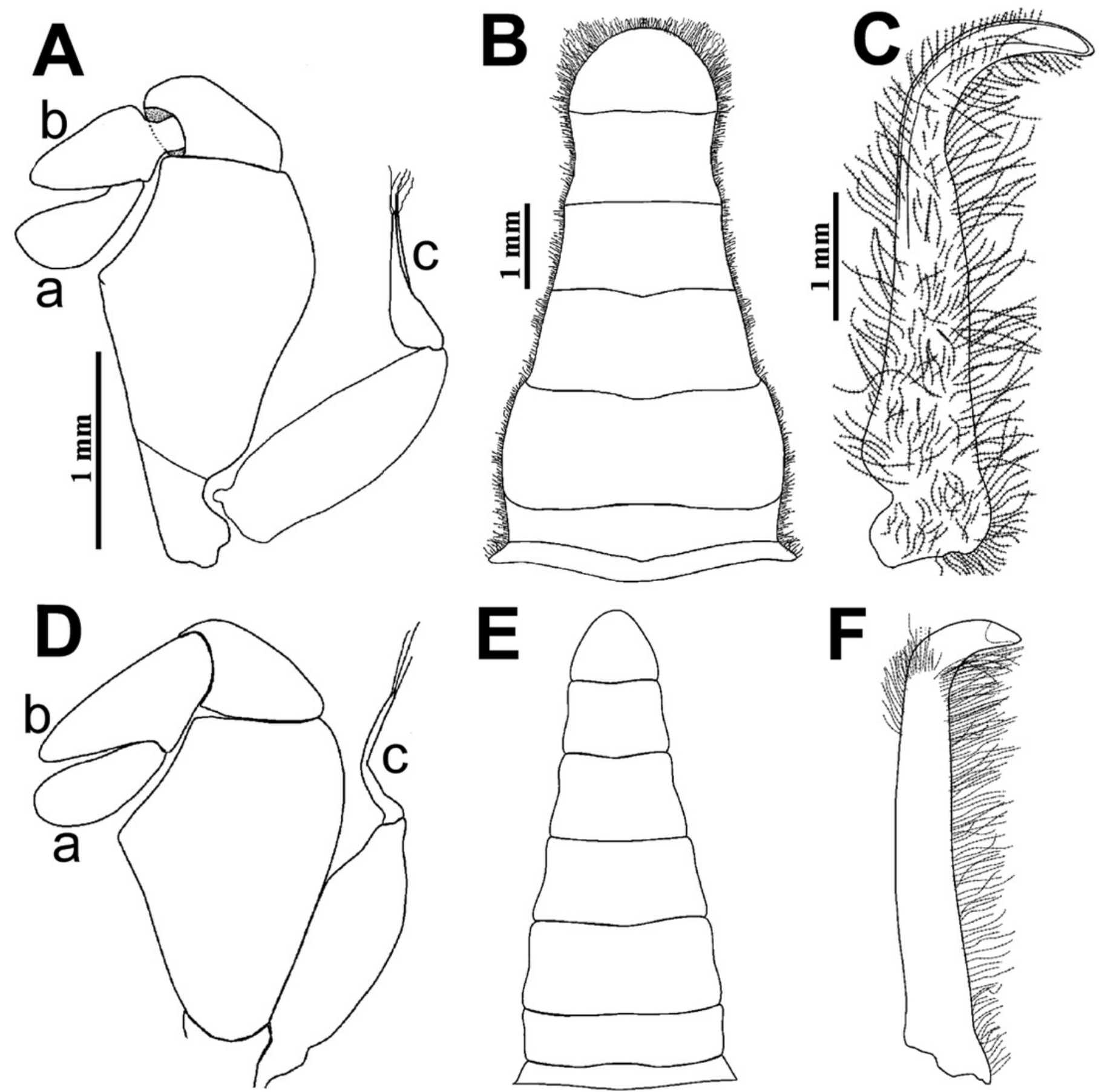
Figure 9

Condensed unrooted Maximum likelihood tree based on mitochondrial cytochrome c oxidase (COI) with the General Time Reversible with gamma distribution (GTR+G) model

Data: BOLD process ID, species name, associated BIN. Branch values represent bootstrap probabilities (1000 permutations). 


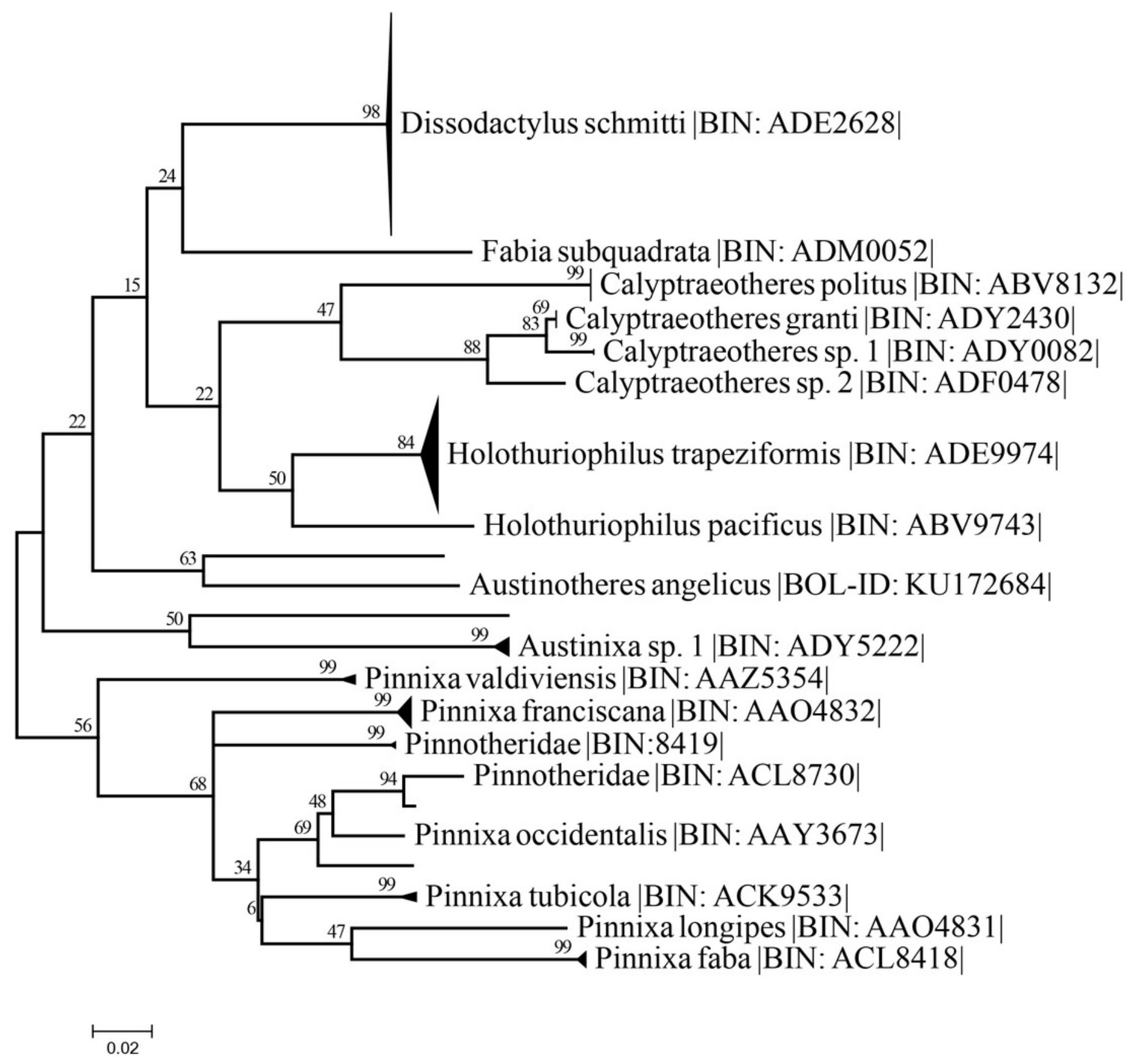

